\title{
MATERIAŁY
}

Witold Chmielewski

BHW 40/2019

Wydziat Pedagogiczny

ISSN 1233-2224

Akademia Ignatianum w Krakowie

DOI: $10.14746 /$ bhw.2019.40.6

ORCID: 0000-0001-5816-5586

\section{Profesor Tadeusz Sulimirski, współorganizator szkolnictwa polskiego na uchodźstwie w latach 1941-1947}

\begin{abstract}
Abstrakt. Professor Tadeusz Sulimirski: co-organiser of Polish education in exile, 1941-1947
The aim of the article is to present the achievements of Professor Tadeusz Sulimirski, an archaeologist, in reference to organising and managing Polish education in exile, 1941-1947. The biographical method prevails in this research paper, presenting one of the leading figures in the Office of Education and School Affairs, as well as the Ministry of Religious Denominations and Public Enlightenment of the Polish government in exile. Tadeusz Sulimirski launched numerous initiatives aimed at developing and streamlining all the forms of Polish education in exile. He cooperated very closely with General Józef Haller. He devoted much attention to developing Polish higher education in exile. Once the Polish government in London was no longer recognised by the British government, Professor Tadeusz Sulimirski became head of the Department of Education, formed on 7 July 1945, of The Interim Treasury Committee for Polish Questions established by the British. He demonstrated great creativity and organizational skills, while very competently coordinating the gradual discontinuation of Polish education in Great Britain and, to some extent, in some of the British dominions. He took great care of the financial situation of Polish students in Great Britain and in the Middle East. He also received students and schools from General Władysław Anders' Polish II Corps evacuated from Italy to Great Britain.

In the post-war years he was an active member of Polish academic circles. He greatly contributed to the development of Polish education in exile and to establishing Polish identity among war refugees.
\end{abstract}

Keywords: exile, education, management, schools, initiatives

\section{W kraju}

Tadeusz Józef Marian Sulimirski (Lubicz-Sulimirski), prawnik, archeolog, nauczyciel akademicki, jeden z organizatorów polskiej oświaty i szkolnictwa wyższego na obczyźnie, a zwłaszcza w Wielkiej Brytanii od 2. poł. lat 40. do pocz. lat 90. ubiegłego wieku. 
Urodził się w rodzinie przemysłowca naftowego i ziemianina 1 kwietnia 1898 r. w Kobylanach koło Krosna. W dzieciństwie przez 5 lat mieszkał wraz rodzicami w Groznym na północnym Kaukazie. Naukę na poziomie szkoły średniej podjął w latach 1908-1910 w prestiżowym Zakładzie Naukowo-Wychowawczym OO. Jezuitów w Chyrowie (jego młodszy brat Witold przebywał tamże w latach 1909-1910), a następnie kontynuował naukę we Lwowie i gimnazjum niemieckim w Celje (obecnie Słowenia), by w 1916 r. złożyć maturę we Lwowie. W latach 1916-1918 służył w 2. Pułku Ułanów Legionów Polskich. Następnie brał udział w obronie Lwowa, za którą otrzymał odznakę honorową „Orlęta”, później był słuchaczem trzymiesięcznej szkoły podchorążych, służył w 9. Pułku Ułanów Małopolskich, uczestniczył w wojnie polsko-bolszewickiej, podczas której został ranny w sierpniu 1920 r. pod Radziechowem. Służbę w wojsku zakończył w stopniu rotmistrza. Przeżył śmierć brata Witolda, z którym był bardzo związany, poległego we wrześniu tegoż roku pod Zasławiem na Wołyniu.

W 1918 dostał się na Wydział Budowy Maszyn Szkoły Politechnicznej we Lwowie. W istocie jednak nauki nie kontynuował. W latach 1921-1924 studiował prawo i ekonomię na Uniwersytecie Jana Kazimierza we Lwowie, uzyskując doktorat praw. W roku 1925 rozpoczął na Wydziale Humanistycznym tegoż uniwersytetu studia w zakresie przedmiotu głównego - archeologii pradziejowej pod kierunkiem prof. Leona Kozłowskiego i jako przedmiotów pobocznych: antropologii (prof. Jan Czekanowski) i etnografii (Adam Fischer), zwieńczone doktoratem z archeologii pradziejowej (prehistorii) w $1929 \mathrm{r}$. Rozwijając swoje zainteresowania tą dziedziną wiedzy, uzyskał w roku 1931 habilitację. W tymże roku został w zastępstwie za prof. Leona Kozłowskiego kierownikiem Katedry Prehistorii na UJK we Lwowie. Wkrótce doc. Tadeusz Sulimirski stał się członkiem kilku towarzystw naukowych i organizacji społecznych, w tym Komisji Antropologii i Prehistorii Polskiej Akademii Umiejętności w Krakowie. W 1936 r. po śmierci swojego kuzyna doc. Józefa Żurowskiego, który był w trakcie procedury zatrudniania na stanowisko kierownika Katedry Prehistorycznej Archeologii Polski Uniwersytetu Jagiellońskiego, podjął w niej pracę dydaktyczną. Niebawem też został profesorem nadzwyczajnym i kierownikiem tej Katedry ${ }^{1}$.

Pracując na uniwersytetach we Lwowie i Krakowie, prowadził szeroką działalność badawczą w dziedzinie archeologii, głównie na kresach południowo-wschodnich ówczesnej Polski (województwa: lwowskie, stanisławowskie, tarnopolskie i wołyńskie)2 ${ }^{2}$. Realizował także badania w okolicach Krakowa, Karpatach i w województwie śląskim.

${ }^{1}$ Chyrowiacy. Słownik biograficzny wychowanków Zakładu Naukowo-Wychowawczego OO. Jezuitów w Chyrowie, 1886-1939, Wydawnictwo WAM, WSF-P „Ignatianum”, oprac. L. Grzebień, J. Kochanowicz, J. Niemiec, s. 540; W. Rojek, W stużbie Polski i nauki Tadeusz Sulimirski (1898-1983), w: Kimmerowie, Scytowie i Sarmaci. Księga poświęcona pamięci profesora Tadeusza Sulimirskiego, red. J. Chochorowski, Uniwersytet Jagielloński Instytut Archeologii, Kraków 2004, s. 33-35. K. Jażdżewski, Z okazji 70-lecia urodzin profesora Tadeusza Sulimirskiego, „Prace i Materiały Muzeum Archeologicznego i Etnograficznego w Łodzi”, Seria Archeologiczna 1968, nr 15, s. 7-8. s. 356.

2 J. Gurba, Profesor Tadeusz Sulimirski (1IV 1898 - 21VI 1983), „Rocznik Polonijny” 1984-1985, nr 5-6, 
Zwłaszcza ten ostatni obszar badawczy, pomijany przez większość popularyzatorów dorobku naukowego prof. Tadeusz Sulimirskiego, stał się w ostatnich latach przedwojennych ważny i absorbujący w jego aktywności naukowej. Po śmierci bowiem doc. Józefa Żurowskiego, który był także Państwowym Konserwatorem Zabytków Prehistorycznych w Krakowie, obejmującym swoim zasięgiem działania również Śląsk, i z tej racji powierzono mu kierowanie pracami prehistorycznymi Komitetu Wydawnictw Śląskich Polskiej Akademii Umiejętności (nakreślił szczegółowy program badań prehistorycznych na Ślą$\mathrm{sku}^{3}$ ), Sulimirski został jego członkiem i przejął ogólne kierownictwo nad tymi badaniami. Prace archeologiczne PAU prowadziły po polskiej stronie Śląska cztery, a następnie trzy zespoły archeologów, a wśród nich tak wybitni uczeni, jak: prof. Józef Kostrzewski z Poznania, prof. Włodzimierz Antoniewicz z Warszawy, dr hab. Roman Jakimowicz z Warszawy i dr Rudolf Jamka z Krakowa ${ }^{4}$.

W celu zapoznania się ze stanem i organizacją badań prehistorycznych po niemieckiej stronie Śląska oraz z działalnością tamtejszych muzeów archeologicznych, odbył w charakterze kierownika prac prehistorycznych Komitetu Wydawnictw Śląskich PAU podróż do Niemiec od 23 stycznia do 18 lutego 1938 r. ${ }^{5}$ Wyniki przeprowadzonego rozeznania miały przyczynić się do lepszej eksploracji archeologicznej polskiego Śląska. Niestety, nie zostały należycie wykorzystane z powodu wybuchu II wojny światowej. Świadczą jednak o wielkiej trosce, z jaką podchodził Sulimirski do realizacji powierzonego mu zadania. Jego wyjazd na Śląsk niemiecki był uzasadniony również i tym, że po drugiej stronie granicy Niemcy podnieśli ochronę zabytków na wysoki poziom i istniała pilna konieczność dorównania im pod tym względem ${ }^{6}$.

Prowadzone pod kierownictwem Sulimirskiego badania archeologiczne na Śląsku pod koniec okresu międzywojennego przyniosły dobre rezultaty. Dowodzi tego opublikowanie w nadzorowanej przez Romana Jakimowicza serii wydawniczej „Prace Prehistoryczne” Komitetu Wydawnictw Śląskich PAU pięć zeszytów z wynikami badań arche-

3 J. Hulewicz, Wydawnictwa śląskie Polskiej Akademii Umiejętności, w: Polska Akademia Umiejętności 1872-1952. Nauki humanistyczne i społeczne. Materiały z sesji jubileuszowej, Kraków, 3-4 V1973, Zakład Narodowy im. Ossolińskich, Wrocław 1974, s. 60.

${ }^{4}$ Archiwum Nauki Polskiej Akademii Nauk i Polskiej Akademii Umiejętności w Krakowie (dalej: AN PAN i PAU), sygn. PAU I-39, Protokół posiedzenia Komitetu Wydawnictw Śląskich Polskiej Akademii Umiejętności w dniu 30 listopada 1938; Rocznik Polskiej Akademii Umiejętności Rok 1937/1938, Nakł. Polskiej Akademii Umiejętności Skład Główny w Księgarniach Gebethnera i Wolffa, Kraków 1939, s. 6; Sprawozdanie z działalności Komitetu Wydawnictw Śląskich Polskiej Akademii Umiejętności za czas od 28 listopada 1935 do 21 listopada 1936 oraz program prac na rok budżetowy 1937/38. Drukowane jako rękopis, Polska Akademia Umiejętności, Kraków 1937, s. 1.

${ }_{5}$ AN PAN i PAU, sygn. PAU I-39, Protokół posiedzenia Komitetu Wydawnictw Śląskich Polskiej Akademii Umiejętności $w$ dniu 30 listopada 1938.

${ }^{6}$ J. Hulewicz, Wydawnictwo śląskie Polskiej Akademii..., op. cit., s. 61. 
ologicznych ${ }^{7}$ oraz ukazanie się pierwszego zeszytu Atlasu grodzisk i zamczysk ślaskich ${ }^{8}$. Owoce tych inicjatyw naukowych widoczne są także w publikacjach archeologicznych po 1945 r. ${ }^{9}$ Na uwagę zasługuje również fakt, że udało się zrealizować, dzięki m.in. staraniom Tadeusza Sulimirskiego, wysuwany od pewnego czasu postulat utworzenia w Muzeum Śląskim w Katowicach działu przedhistorycznego i ustanowienia etatu kustosza prehistoryka, na który wskazano mgr. Jana Bartysa ${ }^{10}$.

Wybuch II wojny światowej przerwał bardzo dobrze rozwijającą się pracę naukowo-badawczą młodego uczonego. Spowodował zmianę jego planów życiowych i doprowadził do opuszczenia ojczystego kraju, jak pokazała przyszłość, na stałe.

\section{Działalność w polskich władzach oświatowych w Londynie}

We wrześniu 1939 r. Tadeusz Sulimirski wyjechał z Polski przez Rumunię do Francji, w której służył w polskim wojsku od października 1939 r. do czerwca 1940 r., m.in. pracował w sztabie gen. Stanisława Maczka. Pod koniec czerwca, po upadku Francji, przybył na pokładzie statku pasażerskiego M.S. „Batory” na Wyspy Brytyjskie. Do kwietnia 1941 r. służył na terenie Anglii i Szkocji w jednostkach wojskowych I Korpusu Polskiego. W tym czasie zaangażował się w utworzenie Federacji Zachodnio-Słowiańskiej, w skład której miała wchodzić Polska i Czechosłowacja, wyrażając poparcie dla koncepcji ustanowienia granicy polsko-niemieckiej na Odrze i Nysie ${ }^{11}$. Zwolennicy tej myśli politycznej, którym przewodził właśnie Profesor, skupiali się wokół wydawanego w latach 1940-1942 „Biuletynu Zachodnio-Słowiańskiego”'2. Warto tu zauważyć, że idee bliskiej współpracy, a nawet federalizacji Polski i Czechosłowacji były dosyć powszechne na obczyźnie i nieobce kierującemu polskim szkolnictwem na uchodźstwie Urzędowi Ministra Gen. Broni Józefa Hallera, a przede wszystkim samemu generałowi ${ }^{13}$. Kontakty w sprawie bliższej współpracy pomiędzy polskimi i czechosłowackimi władza-

7 W. Chmielewski, Z działalności Komitetu Wydawnictw Śląskich Polskiej Akademii Umiejętności w latach 1933-1939, „Studia Śląskie”, Seria nowa, 1976, t. XXIX, s. 341-342.

${ }^{8}$ Atlas grodzisk $i$ zamczysk śląskich z. 1, oprac. J. Żurowski, R. Jakimowicz, Nakł. Polskiej Akademii Umiejętności Skład Główny w Księgarniach Gebethnera i Wolffa, Kraków 1939.

9 W. Chmielewski, Z działalności Komitetu..., op. cit., s. 342; J. Hulewicz, op. cit., s. 61.

${ }^{10}$ AN PAN i PAU, sygn. PAU I-39, Protokół posiedzenia Komitetu Wydawnictw Śląskich Polskiej Akademii Umiejętności $w$ dniu 30 listopada 1938.

11 W. Rojek, op. cit., s. 35-36; T. Radzik, Profesor Tadeusz Sulimirski-archeolog (1898-1983), w: Kimmerowie, Scytowie i Sarmaci. Księga poświęcona pamięci profesora Tadeusza Sulimirskiego, red. J. Chochorowski, Uniwersytet Jagielloński Instytut Archeologii, Kraków 2004, s. 17.

12 S. Grabski, Pamiętniki, t. 2, do druku przygotował i wstępem opatrzył W. Stankiewicz, Czytelnik, Warszawa 1989, s. 396, 482.

13 Szerzej: W. Chmielewski, Działalność oświatowa Urzędu Ministra Gen. Broni Józefa Hallera, „Przegląd Historyczno-Oświatowy" 2013, nr 3-4, s. 56-69. 
mi oświatowymi, przebywającymi na uchodźstwie w Wielkiej Brytanii, zostały zapoczątkowane na konferencji pedagogicznej krajów sprzymierzonych, zorganizowanej w Oksfordzie 4 i 5 stycznia 1941 r. przez uczonych brytyjskich. Z inicjatywy uczestniczących w konferencji przewodniczących delegacji emigracyjnych władz oświatowych Czechosłowacji - syna prezydenta kraju Benesza juniora i Polski - doc. Mariana Jedlickiego, kierownika Wydziału (początkowo Sekcji) Szkolnictwa w Biurze Ministra Gen. Broni Józefa Hallera zorganizowano wspólne zebranie przedstawicieli obu państw. Na spotkaniu tym przyjęto uzgodnioną rezolucję oraz sformułowano szereg postulatów z zamiarem ich realizacji w przyszłości. Między innymi zaproponowano współpracę pomiędzy oboma państwami na rzecz zbliżenia kulturalnego przez stworzenie grup korespondencyjnych, wymianę wizyt i odczytów oraz opracowanie samouczków do nauki języka polskiego i czeskiego. Zamierzano także opracować i wydać broszury o wzajemnych stosunkach kulturalnych, a także zorganizować wspólny zjazd nauczycieli z obu państw. Praktyczną realizacją idei współpracy był udział delegacji emigracyjnego rządu Czechosłowacji na czele z ministrem spraw wewnętrznych, ostatnim posłem tego kraju w przedwojennej Polsce Jurajem Slavikiem ${ }^{14}$.

Jeśli zaś chodzi o kwestię granicy na Odrze i Nysie i ziemie rewindykowane oraz objęcie ich polską administracją jeszcze przed zawarciem powojennego traktatu pokojowego, to prof. Tadeusz Sulimirski proponował przejściowo utrzymać najnowszy podział administracyjny tych obszarów, wprowadzony przez Niemców. Był zdania, że:

podział niemiecki nie jest zły. Połaczył on na nowo dawne prowincje sztucznie pokrajane przez rozbiory Polski. Stworzyt Wielki Ślask, w którym w petni uświadomiony element polski, o ile $w$ ogóle nie ma przewagi, to $w$ każdym razie stanowi dostateczna siłę, by mógt opanować caty Ślask. To samo dotyczy Wielkiego Pomorza i Prus Zachodnich ${ }^{15}$.

Nie jest wykluczone, że zbieżność zainteresowań i poglądów w dziedzinie współpracy polsko-czechosłowackiej mogła być jednym z ważnych czynników branych pod uwagę przy zatrudnianiu prof. Tadeusza Sulimirskiego od maja 1941 r. w Urzędzie Oświaty i Spraw Szkolnych i zarazem bezterminowym urlopowaniu z wojska z końcem kwietnia. Zgodnie bowiem z dekretem Prezydenta Rzeczypospolitej w dniu 1 maja 1941 r. powołany został Urząd Oświaty i Spraw Szkolnych ${ }^{16}$. Kierownikiem urzędu pozostał w randze ministra z uprawnieniami Ministra Wyznań Religijnych i Oświecenia Publicznego gen. broni Józef Haller. Merytoryczne zadania nowo powołanej instytucji administracyjnej określone zostały w artykule 2 dekretu, w którym stwierdzono, że do zakresu jej działania należy:

\footnotetext{
${ }^{14}$ Instytut Polski i Muzeum im. Władysława Sikorskiego w Londynie (dalej: IPMS), zespół: Ministerstwo Wyznań Religijnych i Oświecenia Publicznego (dalej: MWRiOP), sygn. A. 19. I/7, Sprawozdanie z działalności Urzędu Ministra Gen. Broni Józefa Hallera za czas od 15 sierpnia 1940 do 15 marca 1941.

15 IPMS, Kol. 548/8, Notatka T. Sulimirskiego z 11 września 1941 r.

${ }^{16}$ Dekret Prezydenta Rzeczypospolitej z dnia 1 maja 1941r. o utworzeniu Urzędu Oświaty i Spraw Szkolnych, Dziennik Ustaw Rzeczypospolitej Polskiej (dalej: DzURP) 1941, nr 3, poz. 5.
} 
1) Opieka nad kształceniem $i$ wychowaniem młodzieży polskiej na terenie emigracji $w$ zakresie szkolnictwa średniego i powszechnego.

2) Ewidencja nauczycieli szkót średnich i powszechnych na emigracji oraz opieka nad nimi.

3) Wspótdziałanie z władzami wojskowymi $w$ dokształcaniu żotnierzy polskich.

4) Opieka nad wydawnictwami w zakresie szkolnictwa średniego i powszechnego.

5) Przygotowywanie materiałów, dotyczących szkolnictwa średniego i powszechnego w Polsce ${ }^{17}$.

Organizację pracy UOiSS ustalał uchwalony przez Radę Ministrów w dniu 6 maja 1941 r. statut, porównaj: aneks nr 1. Przewidywał on istnienie dwóch wydziałów: ogólnego i szkolnictwa. Kierownikiem pierwszego z nich (głównego) został prof. Tadeusz Sulimirski, a drugiego - dr Franciszek Lenczowski, nauczyciel gimnazjalny z Chorzowa, służący kiedyś w „błękitnej armii’ we Francji, dowodzonej przez gen. Hallera. Obydwie postacie odegrały wielką rolę w organizowaniu pracy polskiego szkolnictwa na obczyźnie. Ich znaczenie było tym większe, że gen. Józef Haller, człowiek o wielkim poczuciu obowiązków patriotycznych i żołnierskich, zwolennik wychowania młodzieży polskiej, na światłych i rozumnych obywateli w duchu propagowanym najpierw przez Stanisława Konarskiego, a następnie przez Komisję Edukacji Narodowej, od młodych lat związany $\mathrm{z}$ harcerstwem, nie miał doświadczenia w kierowaniu złożonymi procesami rządzącymi każdym szkolnictwem, a zwłaszcza w trudnych warunkach życia uchodźczego ${ }^{18}$.

Wspominając kwestię zatrudnienia prof. Sulimirskiego na wakujące miejsce po doc. Marianie Jedlickim, niesłusznie źle przez siebie ocenianego, gen. Haller po latach pisał:

Musiałem więc szukać odpowiedniego człowieka na następcę kierownika głównego wydziału oświaty. W tym celu trzeba było znów jeździć do Perth w Szkocji, gdzie dowódca Korpusu Wojsk Polskich byt gen. [Marian] Kukiel, u którego w sztabie pracowat kpt. Sulimirski, profesor Uniwersytetu Jagiellońskiego. Nie byt on, co prawda pedagogiem i wychowaniem mtodzieży się nie zajmowat jako prehistoryk $i$ archeolog, ale potrafitem go pozyskać i muszę przyznać że wybór byt dobry, bo otwarty umyst tego poważnego profesora tatwo pokonat wszelkie trudności, zwłaszcza gdy miał moje całkowite zaufanie i pomoc grona nauczycielskiego ${ }^{19}$.

Prof. Tadeusz Sulimirski, pełniąc swoją odpowiedzialną funkcję, dokładał wszelkich starań, aby polskie szkolnictwo na uchodźstwie działało sprawnie i kształciło polskie dzieci oraz młodzież z myślą o powrocie do Polski, a następnie pracy dla jej rozwoju. Z uwagi na fakt, że Wydział Szkolnictwa usytuowany został, z powodu rozmieszczenia polskich szkół w Szkocji, w Perth i pełnił zarazem rolę kuratorium, prof. Tadeusz Sulimirski, urzędując w Londynie spełniał zarazem funkcję nieformalnego zastępcy gen. Jó-

17 Ibidem.

18 IPMS, MWRiOP, sygn. A. 19. I/13 c. Przemówienie generała broni Józefa Hallera wygłoszone na Zjeździe Nauczycieli Szkót Średnich i Powszechnych w Perth dnia 6 marca 1941; W. Chmielewski, Poglądy gen. Józefa Hallera na wychowanie w latach 1940-1943, „Przegląd Historyczno-Wojskowy” 2009, nr 4, s. $190-193$.

19 J. Haller, Pamiętniki z wyborem dokumentów i zdjęć, Wydawnictwo LTW, Łomianki 2015, s. 373. W strukturze UOiSS głównym wydziałem była jednostka organizacyjna zajmująca sie sprawami ogólnymi, które wcześniej należały do kompetencji Wydziału Szkolnictwa pod kierownictwem M. Jedlickiego. 
zefa Hallera i reprezentował go na posiedzeniach rządu (nieobecność generała wynikała z częstych chorób) i w roboczych kontaktach międzyresortowych, był także niejednokrotnie przekazicielem decyzji i ustaleń podjętych w UOiSS w Londynie do Wydziału Szkolnictwa w Perth, np. w sprawie nauczania religii w zorganizowanych kompletach polskich przy powszechnych szkołach brytyjskich na terenie Szkocji przez Olgę Biernacką i Joannę Jurgaś. Wizytatorem nauki religii został ks. Stanisław Sinkowski, szef Duszpasterstwa I. Korpusu Polskiego w Szkocji ${ }^{20}$. Przez jego ręce przechodziły wszystkie projekty aktów prawnych, ważniejsze dokumenty i opracowania analityczne oraz przemówienia gen. Józefa Hallera. Był jego prawą ręką.

Oficjalnie jednak prof. Tadeusz Sulimirski nie był, wbrew temu co pisano ${ }^{21}$, zastępcą ministra, kierownika UOiSS. W strukturze organizacyjnej tej instytucji rządowej nigdy nie było takiego etatu.

Pragnąc jak najlepiej wywiązywać się z przyjętych zdań, starał się często osobiście rozwiazywać pojawiające problemy. W sierpniu 1941 r. towarzyszył gen. Józefowi Hallerowi w podróży służbowej do polskich placówek oświatowych w Szkocji od 8 do 19 sierpnia $1941 \mathrm{r}$. W gimnazjum i liceum żeńskim uczestniczył w podejmowaniu ustaleń na temat ewentualnej zmiany dyrekcji tej szkoły i zawarcia nowego kontraktu najmu jej siedziby Scone Palace koło Perth. Z kolei w gimnazjum i liceum męskim w Dunalastair House podjęta została kwestia wynajęcia nowego budynku, w celu powiększenia internatu oraz przeanalizowano zagadnienia budżetowo-gospodarcze. W ośrodku szkolnym w Glasgow omówiono problemy związane z utworzeniem kursu gimnazjalnego. Odwiedził Dowództwo I Korpusu Polskiego w sprawie odkomenderowania żołnierzy na organizowany kurs maturalny w Glasgow. Przeprowadził rozmowy z byłym dyrektorem gimnazjum handlowego w Polsce mgr. Władysławem Jędralem na temat organizowania przez niego korespondencyjnych kursów handlowych. Był także w obozie izolacyjnym w Rothesay na wyspie Bute w pobliżu Glasgow, gdzie zaproponował zorganizowanie dla przetrzymywanych tam wojskowych kursów handlowych ${ }^{22}$.

Zajął jasne stanowisko wobec kwestii podwyższenia subwencji dla szkoły powszechnej w Castlemains, prowadzonej przez Olgę Małkowską. Zwiększenie dofinansowania uzależnił od rezultatów wizytacji tej placówki²3.

Podjął starania o założenie ośrodków nauczania na poziomie średnim i powszechnym (dla dzieci wojskowych), obejmujące, jak to określił ważniejsze polskie „skupienia lotnicze”. W trakcie trzydniowej podróży do Blackpool odnotował, że ośrodek ten, podobnie

\footnotetext{
${ }^{20}$ IPMS, MWRiOP, sygn. A. 19. I/10/ a-d, Pismo T. Sulimirskiego z 23 czerwca 1941 roku do Wydziału Szkolnictwa w sprawie zorganizowania nauczania religii na kompletach polskich.

21 J. Jasnowski, Prof. Tadeusz Sulimirski jako organizator szkolnictwa polskiego na emigracji, „XXVII Rocznik Polskiego Towarzystwa Naukowego na Obczyźnie 1984/84”, (Londyn) 1984, s. 123.

22 IPMS, MWRiOP, sygn. A. 19. I/9. T. Sulimirski, Sprawozdanie z podróży służbowej odbytej z P. Ministrem gen. Broni Józefem Hallerem w czasie od 8 VIII do 19 VIII 1941 roku.

${ }^{23}$ Ibidem, sygn. A. 19. I/ 11, Pismo T. Sulimirskiego z 21 sierpnia 1941 roku do Wydziału Szkolnictwa w sprawie podwyższenia subwencji dla szkoły powszechnej Olgi Małkowskiej w Castlemains.
} 
jak i powstająca podobna placówka w Hamswel mają możliwości, mimo znacznych braków kadrowych, do prowadzenia działalności dydaktycznej. Obydwa ośrodki miały być przeznaczone także dla polskich lotników z innych pobliskich miejscowości ${ }^{24}$.

W czasie służbowego pobytu w Szkocji 20 października 1941 r. stwierdził szereg uchybień natury organizacyjnej i merytorycznej w organizowaniu kursu przez Samodzielny Referat Propagandy i Oświaty I Korpusu Polskiego, w dodatku bez porozumienia z UOiSS. Sformułowane uwagi pod adresem organizatora kursu były na tyle istotne i miały wpływ na dalszą współpracę władz oświatowych z wojskiem, że gen. Józef Haller zdecydował się poinformować o nich Naczelnego Wodza ${ }^{25}$. W kolejnych dniach podróży wizytował kilka szkół i wygłosił odczyt dla 150 osób na Uniwersytecie w Glasgow na temat dziejów Polski. Wiele uwagi poświęcił organizowaniu kursów dla nauczycieli służących w wojsku, niejednokrotnie był zmuszony w złożonej sytuacji funkcjonowania uchodźstwa rozstrzygać skomplikowane kwestie szczegółowe natury organizacyjnej, finansowej, czy też kadrowej ${ }^{26}$. Z polecenia gen. Hallera wizytował Willingdon College w Milborne Port. Celem tej wizyty, odbytej w odpowiedzi na kilkakrotnie ponawiane zaproszenie dyrekcji szkoły, było zapoznanie się z działalnością placówki prywatnej, zorganizowanej na wzór szkoły publicznej ${ }^{27}$.

Podczas następnych odwiedzin polskich placówek oświatowych w Szkocji od 19 do 26 czerwca 1942 r. podjął decyzje w wielu sprawach organizacyjnych i finansowych, dotyczących polskich placówek szkolnictwa zawodowego w tej części Wielkiej Brytanii oraz przeanalizował możliwość zorganizowania liceum handlowego w Glasgow. Odbył naradę z dr. Janem Konopnickim i Władysławem Jędralem w sprawie przyspieszenia, prowadzonych dotąd niezbyt skutecznie, badań nad szkolnictwem brytyjskim. Należy tu odnotować, że niebawem osiągnęły one jak na istniejące możliwości kadrowe i uwarunkowania wojenne, znaczne rozmiary ${ }^{28}$. Z osobami tymi przedyskutował także kwestię zorganizowania kilkumiesięcznego kursu pedagogicznego dla nauczycieli służących w wojsku w zakresie przedmiotów pedagogicznych (na bazie absolwentów tego kursu i z uwzględnieniem zdobytych w trakcie jego trwania doświadczeń, w 1943 r. powstało

\footnotetext{
${ }^{24}$ Ibidem, sygn. A. 19. I/9. T. Sulimirski, Sprawozdanie z podróży stużbowej do Blackpool $w$ dniach 1-3.X.1941.

25 Ibidem, sygn. A. 19. I/ 11, Pismo J. Hallera do z 19 listopada 1941 roku do Naczelnego Wodza w sprawie organizowania kursu przez Samodzielny Referat Propagandy i Oświaty I Korpusu Polskiego.

${ }^{26}$ Ibidem, sygn. A. 19. I/9, T. Sulimirski, Sprawozdanie z podróży służbowej, odbytej od dnia 18 X 1941 wieczorem do dnia 28 X 1941 rano.

${ }^{27}$ Ibidem, T. Sulimirski, Sprawozdanie z podróży służbowej, odbytej dnia 2 grudnia 1941 do Willingdon College w Milborne Port.

28 T. Sulimirski, Studium Pedagogiczne w Edynburgu (1943-1946), „Nauka Polska na Obczyźnie” 1955, z. 1, s. 50; W. Chmielewski, Przygotowanie kadr oświatowych na uchodźstwie, Seria: Monografie z Dziejów Oświaty, t. XVIII, Instytut Historii Nauki im. Ludwika i Aleksandra Birkenmajerów Polskiej Akademii Nauk, Warszawa 2013, s. 53-61.
} 
polskie Studium Pedagogiczne na Uniwersytecie w Edynburgu ${ }^{29}$. Podjął również rozmowy z firmą wydawniczą w sprawie drukowania podręczników dla szkół w Polsce po zakończeniu działań wojennych. Był jednym z pierwszych przedstawicieli władz polskich w Wielkiej Brytanii, który odwiedził i zatroszczył się o 629 Polaków przybyłych ze Związku Sowieckiego, i umieszczonych w obozie w Anchtortool (95 absolwentów gimnazjum ogólnokształcącego, 22 - gimnazjum technicznego, 152 gimnazjum zawodowego (handlowego), 75 - liceum ogólnokształcącego, 275 szkoły powszechnej i 10 osób mających wykształcenie wyższe) ${ }^{30}$.

$\mathrm{Na}$ początku lat 40. zdecydowana większość nauczycieli pełniła służbę żołnierską w polskich oddziałach wojskowych w Wielkiej Brytanii, zwłaszcza w Szkocji. Z tego powodu pojawiało się wiele problemów dotyczących współpracy władz oświatowych z poszczególnymi jednostkami wojskowymi. W tej sytuacji prof. Tadeusz Sulimirski wiele uwagi poświęcał bezpośrednim kontaktom z dowództwami wojskowymi różnych szczebli, w celu omówienia najważniejszych, bieżących kwestii edukacyjnych i kadrowych dotyczących m.in. urlopowania nauczycieli w mundurach do pracy, bądź ich uczestnictwa w różnych formach życia oświatowego. Do załatwiania tych spraw wykorzystywał swój pobyt w rejonie postoju jednostek wojskowych w Szkocji. Np. 16 maja 1942 r. przeprowadził rozmowę z gen. Marianem Kukielem, dowódcą I Korpusu. Przedmiotem spotkania była sprawa odkomenderowania żołnierzy na nowy turnus oraz przedstawienie generałowi zarządu Zrzeszenia Nauczycieli Polaków w Wielkiej Brytanii (przewodniczący - Wilhelm Nowicki, wiceprzewodnicząca - Jadwiga Święcicka i sekretarz Michał Stopa). Ponadto w Samodzielnym Referacie Propagandy i Oświaty I Korpusu omówił sprawę zezwolenia noszenia legitymacji oraz mundurów wojskowych przez nauczycieli gimnazjów, kwestię zapewnienia podręczników szkolnych dla uczestników kursów szkół powszechnych, rozpatrywał skargi wnoszone przez wojskowych na wychowanki polskiego internatu w Scone Palace ${ }^{31}$. Podczas pobytu w Szkocji pod koniec czerwca 1943 r. kontynuował prowadzone w maju rozmowy z wojskiem, w szczególności zaś zabiegał o finansowanie publikacji elementarza i skryptów dla szkół powszechnych, potrzebnych na kursach dla żołnierzy ${ }^{32}$.

Doceniał rolę i znaczenie wychowania dzieci w wieku przedszkolnym. Świadczy o tym jego spotkanie z wybitnym psychologiem, profesorem Uniwersytetu w Toronto Blatzem i dyrektorem Child Study Institute w tej uczelni, który prowadził w Wielkiej Brytanii kursy dla 10 tys. wychowawczyń dzieci ewakuowanych ze swoich miejsc za-

\footnotetext{
${ }^{29}$ T. Sulimirski, Studium Pedagogiczne, s. 50-53; W. Chmielewski, Przygotowanie kadr..., op. cit., s. 75-84, $176-184$.

${ }^{30}$ IPMS, MWRiOP, sygn. A. 19. I/15. T. Sulimirski, Sprawozdanie z podróży stużbowej do Szkocji, odbytej w czasie 19-26 czerwca 1942 roku.

31 Ibidem, T. Sulimirski, Sprawozdanie z podróży służbowej do Szkocji, odbytej w czasie 12-17 maja 1942 roku.

${ }^{32}$ Ibidem, T. Sulimirski, Sprawozdanie z podróży stużbowej do Szkocji, odbytej w czasie 19 m- 26 czerwca 1942 roku.
} 
mieszkania z powodu wojny. W trakcie spotkania prof. Blatz zaproponował wykształcenie sztabu 5-7 polskich instruktorek na rocznym kursie w Kanadzie. Kandydatki do tego kursu, korzystające $\mathrm{z}$ kanadyjskiego stypendium, powinny mieć w zasadzie wykształcenie uniwersyteckie i być przygotowane do przekazywania wiedzy wychowawczyniom skierowanym do bezpośredniej pracy z dziećmi ${ }^{33}$. Niestety z tej śmiałej, wzorowanej na brytyjskich doświadczeniach, inicjatywy edukacyjnej nie skorzystano.

W sierpniu 1942 r. zakres prac kierowanego przez Tadeusza Sulimirskiego Wydziału Ogólnego powiększył się o nowe zadania. Wynikały one z rozszerzonej działalności UOiSS. W ramach wydziału realizował swoje zadania sekretariat całego urzędu, zwłaszcza sprawy zlecone przez gen. Józefa Hallera i referaty: budżetowy, wydawniczy, administracyjny i szkół zawodowych. Prof. Sulimirskiemu podlegały redakcje serii wydawniczych UOiSS: „Pomniki Literatury Ojczystej” i „Nauka i Wychowanie” oraz Komisja Oceny Podręczników i placówka wydawnicza w Edynburgu, a także zyskujący od 1943 r. coraz większe znaczenie ośrodek wydawniczy w Palestynie pod kierownictwem doc. Łukasza Kurdybachy ${ }^{34}$. Priorytet stanowiły wszystkie kwestie związane z wydawaniem podręczników i lektur szkolnych oraz literatury pedagogicznej, a zwłaszcza metodycznej. W Wydziale Ogólnym powstawały projekty budżetowe dla całego szkolnictwa i prowadzono nadzór nad gospodarką wszystkich placówek edukacyjnych. Bardzo ważnym zadaniem było projektowanie aktów prawnych dotyczących oświaty na uchodźstwie i ustanowienie organizacji wewnętrznej UOiSS, a także przygotowanie odbudowy administracji szkolnej w kraju po wojnie, ze szczególnym uwzględnieniem terenów rewindykowanych (sprawą tą zajmował się osobiście prof. Sulimirski). Trzeba zaznaczyć, że zwolennicy rewindykowania tych terenów, do których należał profesor, nie myśleli wówczas o wysiedleniu Niemców z terenów zachodnich i północnych dzisiejszej Polski. Sądzili bowiem, że wśród ludności niemieckiej, zamieszkującej Śląsk i Pomorze Zachodnie będącej, w ich przekonaniu, pochodzenia polskiego przywrócone zostanie w naturalny sposób w drugim pokoleniu poczucie polskości ${ }^{35}$. Do zadań Wydziału należała też opieka nad kursami i szkołami zawodowymi oraz współpraca z władzami wojskowymi w dokształcaniu żołnierzy, a także przygotowanie koncepcji odbudowy szkolnictwa zawodowego w kraju po wojnie ${ }^{36}$.

Prof. Sulimirski należał do pięcioosobowego komitetu koordynującego pracę związaną z nadawaniem przez radio do kraju pogadanek przeznaczonych dla młodzieży. Tematyka pogadanek była szeroka i obejmowała m.in. zagadnienie walki o niepodległość, pracy nad samym sobą według programu filareckiego, wychowanie nowego człowieka,

33 Ibidem, sygn. A. 19. I/15 Notatka z konferencji z Prof. Blatzem Prof. Uniw[ersytetu] Toronto i jego 3 asystentami z prof. Sulimirskim i por. [Józefem] Follprechtem, odbytej dnia 19 IX [19]42.

${ }^{34}$ Por. W. Chmielewski, Działalność wydawnicza polskich władz oświatowych na uchodźstwie w latach 1940-1945, „Przegląd Historyczno-Oświatowy” 2013, nr 1-2, s. 8, 11.

35 S. Grabski, op. cit., t. 2, s. 399.

${ }^{36}$ IPMS, MWRiOP, sygn. A. 19. II/52, Rozporządzenie Ministra, 25 sierpnia 1942 r. 
zerwanie z typem kawiarnianym, szerzenie zasad harcerskich, zwalczanie alkoholizmu i pornografii, propagowanie zdrowego stylu życia i prowadzenie przez radio ćwiczeń cielesnych, organizowanie audycji dla rodziców i nauczycieli, zaznajamianie z historią Polski i propagowanie nauki języków obcych ${ }^{37}$.

Uczestniczył w rozmowach gen. Józefa Hallera 7 kwietnia 1943 r. z ministrem oświaty rządu belgijskiego M. Hoste w sprawie realizacji zagadnień poruszanych na konferencjach Ministrów Oświaty Państw Sprzymierzonych ${ }^{38}$. Przewodniczył 11 czerwca 1943 r. posiedzeniu polskiego zespołu międzyresortowego w sprawie wdrażania w życie rezultatów stałych prac Konferencji Ministrów Oświaty Państw Sprzymierzonych. Zakres tych prac był szeroki, daleko zaawansowany i obejmował przyszłe stosunki kulturalne, odbudowę szkolnictwa, zwłaszcza wyższego w okupowanych obecnie krajach, rewindykację mienia kulturalnego i sprzętu naukowego zagarniętego przez okupantów poszczególnych państw $^{39}$. W tej kwestii pozostawał w kontakcie z Ministerstwem Prac Kongresowych, a zwłaszcza bezpośrednio z ministrem Marianem Seydą. W jednym z pism skierowanych do prof. Tadeusza Sulimirskiego, minister prosił go o zajęcie stanowiska w imieniu władz polskich w sprawie raportu Łącznej Komisji London International Assembly i Council for Education in World Citizenship. Minister Seyda podkreślił, że dokument ten został przygotowany przez osoby z wpływowych organizacji brytyjskich, starających się sformułować zasady i kierunki przyszłej odbudowy i modernizacji świata. Raport dotyczył tak ważnych kwestii, jak: a) stworzenia Biura Narodów Zjednoczonych dla odbudowy wychowania; b) stworzenia Międzynarodowej Organizacji Wychowania, przy czym wychodzi się z założenia wciagnięcia do tej organizacji Niemców; c) ustanowienie Wysokiego Komisarza i osobnej Międzyalianckiej Komisji reedukacji Niemiec ${ }^{40}$.

Podane tu przykłady inicjatyw prof. Tadeusza Sulimirskiego w UOiSS (wszystkich nie sposób wyliczyć) pokazują, jak intensywna i wszechstronna była jego działalność na niwie organizacji i zarządzania szkolnictwem. Dowodzą też jego znakomitej współpracy z gen. Józefem Hallerem, którego często zastępował w rozstrzyganiu problemów i podejmowaniu decyzji.

Dotychczasowa praca, nabyte doświadczenie i głębokie wniknięcie w złożone problemy szkolnictwa polskiego na uchodźstwie oraz troska o perspektywy jego odbudowy i zreformowania w kraju po zakończeniu wojny, pozwoliły prof. Tadeuszowi Sulimirskiemu na opracowanie w czerwcu 1943 r. roboczego, ale ważnego dokumentu pt. Co

\footnotetext{
${ }^{37}$ Ibidem, sygn. A. 19.I/11,T. Sulimirski, Notatka, 29 grudnia 1941 roku.

38 Ibidem, sygn. A. 19.I/18, T. Sulimirski, Sprawozdanie z konferencji u generała Hallera $w$ sprawie wspótpracy Ministrów Oświaty Krajów Sprzymierzonych, dn. 7 kwietnia 1943 r.

39 Ibidem, sygn. A. 19.I/18, Pismo T. Sulimirskiego z 17 czerwca 1943 roku do Ministerstwa Spraw Zagranicznych w sprawie prac Konferencji Ministrów Oświaty Państw Sprzymierzonych.

${ }^{40}$ Ibidem, Pismo M. Seydy z 1 lipca 1943 roku do T. Sulimirskiego w sprawie wniosków w raporcie Łącznej Komisji London International Assembly i Council for Education in World Citizenship.
} 
należy czynić w przyszlości w obrębie Urzędu Oświaty i Spraw Szkolnych? ${ }^{21}$. W 13 punktach ujął on w zarysie najważniejsze, jego zdaniem, zadania, które należało koniecznie zrealizować. Proponował więc, aby prowadzone badania nad szkolnictwem brytyjskim skoncentrować na kilku jego najważniejszych formach, np. na camp schools. Sugerował, aby do placówek brytyjskich skierować na wielomiesięczny staż kilku doświadczonych nauczycieli, wyróżniających się zdolnościami organizacyjnymi. Zdobytą w ten sposób wiedzę i umiejętności spożytkowaliby na zorganizowanie i prowadzenie podobnych szkół, czy też obozów szkolnych w Polsce.

Postulował rozwijanie działań zmierzających do szerokiego korzystania z dorobku brytyjskiego w zakresie wychowania przedszkolnego. Doceniał podejmowane od pewnego czasu inicjatywy w tej dziedzinie przez Amalię Marię Stöcker. Proponował również, aby po wojnie osoby zajmujące się kształceniem kadr dla wychowania przedszkolnego zostały przeszkolone w Polsce przez wspomnianego wyżej prof. Blatza z Kanady. Amalia Maria Stöcker powinna zaś doprowadzić w przyszłości do przyjazdu do Polski angielskich specjalistek z wychowania przedszkolnego.

Szczególnie wiele uwagi poświęcił kształceniu kadr nauczycielskich. Sądził, że również i w tej kwestii należy korzystać z doświadczeń brytyjskich, a zwłaszcza edynburskich (Training College for Teachers). Ważną rolę w tym względzie przewidywał dla dr. Jana Konopnickiego, kierownika polskiego Studium Pedagogicznego na Uniwersytecie w Edynburgu. Był zdania, że należy głęboko przeanalizować politykę państwa wobec młodzieży oraz podjąć działania zmierzające do systemowego wychowania i kształtowania charakteru młodego pokolenia w kraju po wojnie.

Uznał za niezbędne podniesienie poziomu wykształcenia społeczeństwa i stworzenie systemu uzupełniania edukacji szkolnej za pomocą nowoczesnych środków przekazu. W realizacji tego celu widział dużą rolę kształcenia drogą korespondencyjną w połączeniu z nauczaniem przez radio. Przewidywał, że po wojnie w kraju należy utworzyć Instytut Nauczania Korespondencyjnego, który będzie określał metody i formy tego typu edukacji. W realizacji tego zadania zalecał korzystanie z bogatych doświadczeń brytyjskich, jak również dorobku polskich kursów na obczyźnie o tematyce handlowej i technicznej. Osobą pierwszoplanową, przewidzianą do odgrywania wiodącej roli w tego typu edukacji był dr Jan Dąbrowski, mający na tym polu znaczne osiągnięcia, w kierowanej przez niego polskiej placówce oświatowej w Glasgow.

Przedmiotem szczególnej uwagi Tadeusza Sulimirskiego była sprawa odbudowy i zreformowania polskiego szkolnictwa po wojnie. Zagadnienie to znajdowało swoje odzwierciedlenie w intensywnych pracach Komisji Organizacji Szkolnictwa w Okresie Przejściowym (po wojnie) pod kierownictwem dr. Franciszka Lenczowskiego. Oceniając wysoko pracę komisji, uznał, że sformułowana przez nią koncepcja reaktywowania szkolnictwa będzie bardzo przydatna w wolnej Polsce. nych].

${ }^{41}$ Ibidem, sygn. A.19. I/17, Co należy czynić w przyszłości w obrębie Urzędu Ośw[iaty] i Sp[raw] Szk[ol- 
Z podobną troską odnosił się do zagadnienia zapewnienia powojennej szkole nowoczesnych pomocy naukowych. Uważał za niezbędne zakupienie dla każdej szkoły odbiornika radiowego i opracowanie specjalnej sieci radiowej, przeznaczonej tylko dla systemu edukacji. Proponował wyodrębnienie i zakwalifikowanie przez specjalistów odpowiednich filmów do użytku szkolnego. Postulował szybki rozwój bibliotek szkolnych.

Jako zdeklarowany zwolennik granicy Polski na Odrze i Nysie Łużyckiej stwierdził, że w ramach działalności Komisji Organizacji Szkolnictwa w Okresie Przejściowym wyjątkowe znaczenie posiada praca podkomisji zajmującej się szkolnictwem na ziemiach rewindykowanych, znajdujących się obecnie w granicach Niemiec. Uznał za stosowne opracowanie odpowiednich instrukcji na ten temat. Zarys polityki szkolnej na tym obszarze przedstawił w specjalnym referacie (niestety, na referat ten nie natrafiono).

Za niezbędne i bardzo istotne uważał wszechstronne propagowanie spraw polskich na terenie Wielkiej Brytanii. Sądził, że popularyzowanie naszego kraju w społeczeństwie brytyjskim powinno odbywać się przez uczniów polskich w szkołach brytyjskich, wyposażonych w materiały o charakterze propagandowym, a także w drodze organizowania odczytów i koncertów dla młodzieży brytyjskiej. Wszystkie tego typu akcje powinny być koordynowane przez Ministerstwo Informacji i Dokumentacji. Młodzież polska pobierająca naukę w szkołach brytyjskich nie powinna ulegać wynarodowieniu. W tym celu należy tworzyć odpowiednie kluby i wydawać pisemka młodzieżowe integrujące młode pokolenie Polaków, uczących się w różnego typu szkołach na terenie Szkocji i Anglii.

W zakresie polityki wydawniczej i podręcznikowej był zwolennikiem wydawania lub przygotowywania do druku po wojnie jak największej liczby książek i podręczników brytyjskich ze wszystkich dziedzin wiedzy, a zwłaszcza z techniki. Uważał, że przydatne do bieżącej edukacji podręczniki szkolne należy wydawać głównie w polskim ośrodku wydawniczym w Palestynie, ponieważ na Bliskim i Środkowym Wschodzie, a przede wszystkim w Afryce znajduje się najwięcej polskich szkół. Był zdania, że biblioteka UOiSS powinna kupować i gromadzić wszystkie pozycje wydawnicze, dotyczące problematyki oświaty i wychowania oraz udostępniać je stypendystom, studentom i osobom interesującym się tymi zagadnieniami ${ }^{42}$.

Ostatni dezyderat zawarty w roboczej koncepcji zadań oświatowych sformułowanych przez prof. Tadeusza Sulimirskiego podejmował kwestię udziału Polski w pracach Konferencji Ministrów Oświaty Państw Sprzymierzonych. Był zdania, że wyłoniona na niej specjalna komisja skoncentruje swoją uwagę na kwestii pomocy państwom okupowanym przez Niemców w zakresie odbudowy po wojnie nauki, szkolnictwa, bibliotek i innych instytucji oświatowo-kulturalnych.

Sformułowane w zarysie zamierzenia i plany prof. Tadeusz Sulimirski nie zdążył rozwinąć, czy też w niektórych przypadkach bliżej sprecyzować. Wiele jednak z nakreślonych przez niego zadań było realizowanych w innej sytuacji personalnej zarządzania

\footnotetext{
${ }^{42}$ Ibidem.
} 
oświatą na obczyźnie. Dobiegał bowiem nieuchronnie okres kierowania szkolnictwem przez gen. Józefa Hallera. Pod koniec maja 1943 r. otrzymał on pismo od prezesa Rady Ministrów gen. Władysława Sikorskiego następującej treści:

zawiadamiam Pana Ministra, że Rada Ministrów na posiedzeniu w dniu 22 maja 1943 roku uchylita swoja uchwate z dnia 29 lipca 1940 roku o powierzeniu Panu Ministrowi spraw wychowania narodowego i równocześnie powzięła uchwałę o poruczeniu Mu urzędu Ministra Delegata Rządu do Spraw Polskich na Wschodzie. Uprawnienia Pana Ministra jako Delegata Rządu normuje instrukcja, uchwalona przez Radę Ministrów w dniu 17 maja 1943 r. Odpis instrukcji załączam do wiadomości Pana Ministra ${ }^{43}$.

Uchwała Rady Ministrów nie została zrealizowana, ponieważ kilka tygodni później w katastrofie gibraltarskiej zginął gen. Władysław Sikorski. Na przeszkodzie wdrożenia jej w życie stanął też stan zdrowia i wiek gen. Hallera. W międzyczasie powołano nowy rząd pod kierownictwem Stanisława Mikołajczyka. Utworzono w nim 14 lipca 1943 r. Ministerstwo Wyznań Religijnych i Oświecenia Publicznego. Ministrem tego resortu został ks. prałat szambelan papieski dr Zygmunt Kaczyński ${ }^{44}$. Dzień później gen. J. Haller zwrócił się z listem pożegnalnym do osób, z którymi był szczególnie w ostatnich latach blisko związanych. Pisał w nim:

Wszystkim moim wspótpracownikom Urzędu Oświaty i Spraw Szkolnych, którzy wykazali tyle sumiennego wysitku w celu dobrego wypetnienia swoich obowiązów i powodowani rzeczywistą miłościa Ojczyzny, pragnac oddać Jej jak najlepsze usługi, wyrażam uznanie na ręce moich najbliższych wspótpracowników i kierowników dwóch najważniejszych wydziatów Prof. Dr. Tadeusza Sulimirskiego i Dr. Franciszka Lenczowskiego ${ }^{45}$.

W strukturze nowo utworzonego Ministerstwa WRiOP przewidziano stanowisko sekretarza generalnego, faktycznie zastępcy ministra. Został nim świetnie zapowiadający się uczony z Krakowa, związany z Uniwersytetem Jagiellońskim i Akademią Górniczą, prof. Adam Skąpski ${ }^{46}$. Prof. Tadeusz Sulimirski pozostał nadal kierownikiem najbardziej rozbudowanego w Ministerstwie WRiOP Działu Ogólnego (w strukturze organizacyjnej ministerstwa dział odpowiadał dawnemu departamentowi). Ta jednostka administracyjna miała charakter gospodarczy i organizacyjny. Zajmowała się sprawami kadrowymi, wychowaniem młodzieży oświatą pozaszkolną kontaktami międzynarodowymi w dziedzinie oświaty, zarządzaniem biblioteką. W jej skład wchodziły referaty: studiów (realizował prace dotyczące przyszłej reformy szkolnictwa), młodzieży, wydawniczy i biblioteczny ${ }^{47}$.

${ }^{43}$ Muzeum Wojska Polskiego w Warszawie (dalej: MWPL), sygn. mwp2467c. Pismo W. Sikorskiego z 24 maja 1943 roku do J. Hallera w sprawie odwołania go z funkcji zarządzającego polską oświatą.

${ }^{44}$ R. Gajewski, Ks. Zygmunt Kaczyński Kapłan i polityk, System Graf, Lublin 2013, s. 167-263; W. Chmielewski, Polska administracja szkolna w latach 1944-1950, Piotrków Trybunalski, Uniwersytet Jana Kochanowskiego w Kielcach Filia w Piotrkowie Trybunalskim, wyd. 2, Piotrków Trybunalski, s. 49-71. 1943 rok.

${ }^{45}$ MWPL, sygn. mwp13258c, J. Haller, Do moich wspótpracowników i ukochanej młodzieży, 15 lipca

46 W. Chmielewski, Przygotowanie kadr.., op. cit., s. 52.

47 W. Chmielewski, Polska..., op. cit., s. 51, 52. 
Szczególnie ważna dla działalności polskiego szkolnictwa na uchodźstwie była wówczas kwestia zapewnienia uczniom podręczników i lektur szkolnych. Zadanie to realizowały dwa ośrodki wydawnicze. Mniejszy w Wielkiej Brytanii i znacznie większy pod kierownictwem doc. Łukasza Kurdybachy w Palestynie ${ }^{48}$. Praca w tym zakresie prowadzona była nieomal od początku istnienia polskich władz oświatowych, ale największe jej rezultaty odnotowano w okresie działalności Ministerstwa WRiOP.

Prof. Tadeusz Sulimirski aktywnie uczestniczył w pracach powołanej przez ks. ministra WRiOP Zygmunta Kaczyńskiego Komisji Odbudowy Szkolnictwa i Reformy Ustroju Szkolnego, m.in. przewodniczył Podkomisji Bibliotek, Podręczników Szkolnych i Pomocy Naukowych oraz Budownictwa Szkolnego ${ }^{49}$. W skład komisji wchodzili: kpt. F. Babirecki, inż. Tadeusz Cwynarski, mgr Maria Danilewiczowa, dr Józef Jasnowski, doc. dr Marian Książkiewicz, Arkadiusz Malinowski, T. Sawicki, J. Święcicka, prof. dr F. Zweig ${ }^{50}$. Prowadzone pod jego kierownictwem obszerne prace komisji obejmowały nie tylko aktualne sprawy na uchodźstwie, ale także zawierały plany rozwiązań kwestii podręczników, bardzo dokładne koncepcje budownictwa szkolnego ${ }^{51}$ oraz propozycje zaopatrzenia bibliotek w Polsce po zakończeniu wojny. Dorobek biblioteki Polskiej w Londynie w czasie wojny pod życzliwym patronatem Profesora i bardzo dobrym kierownictwem Marii Danilewiczowej zasługuje tu na szczególną uwagę ${ }^{52}$. Tadeusz Sulimirski był też członkiem Komisji Bibliotecznej, utworzonej przez ks. Zygmunta Kaczyńskiego 12 listopada 1943 r. Celem komisji, pracującej pod przewodnictwem sekretarza generalnego Ministerstwa WRiOP prof. Adama Skąpskiego, było wydawanie opinii o zakupie i gromadzeniu książek, podręczników i wydawnictw naukowych dla bibliotek krajowych ${ }^{53}$.

Jako gorący patriota prof. T. Sulimirski nie stronił od działalności na rzecz zachowania kresów wschodnich w granicach odrodzonego państwa polskiego. Na zjeździe organizacyjnym w Edynburgu Związku Ziem Południowo-Wschodnich Rzeczypospolitej Polskiej 17 października 1943 r. wybrany został członkiem jego Komisji Rewizyjnej ${ }^{54}$.

Pod koniec 1944 r. we władzach polskich na uchodźstwie zaszły ważne zmiany, które wpłynęły na sytuację prof. Sulimirskiego w Ministerstwie WRiOP. Na skutek braku

48 J. Draus, Działalność oświatowa Łukasza Kurdybachy w latach 1940-1946, „Rozprawy z Dziejów Oświaty" 1984, t. XXVI, s. 218-227; W. Chmielewski, Działalność wydawnicza..., op. cit., s. 5-16.

${ }^{49}$ IPSM, MWRiOP, sygn. A. 19. III/58, Pisma T. Sulimirskiego z 12 kwietnia i 7 listopada 1944 roku do członków Podkomisji w sprawie zebrania na temat radiofonii w szkołach.

50 Ibidem, sygn. A. 19.II/3, Posiedzenie Podkomisji Bibliotek, Podręczników Szkolnych i Pomocy Naukowych, dnia 16 czerwca 1944 r., godz. 15.

${ }^{51}$ Ibidem, sygn. A. 19. II/47 Komisja Odbudowy Szkolnictwa i Reformy Ustroju Szkolnego. Teza XII: Zagadnienie budynków szkolnych; Teza XVIII: Tezy budownictwa szkolnego.

52 M. Danilewicz, Biblioteka Polska w Londynie, „Nauka Polska na Obczyźnie” 1958, z. 2, s. 103-108.

53 W. Chmielewski, Polska administracja..., op. cit., s. 53. Członkami tej komisji byli także: Paweł Skwarczyński, Jan Hulewicz i Maria Danilewicz.

${ }^{54}$ IPMS, Kol. 548/11, Pismo P. Siekanowicza z 22 października 1943 roku do T. Sulimirskiego, informujące go wyborze na członka Komisji Rewizyjnej. 
akceptacji dla swoich działań politycznych 24 premier Stanisław Mikołajczyk złożył dymisję swojego gabinetu. Powstawał nowy rząd pod kierownictwem Tomasza Arciszewskiego, ks. Zygmunt Kaczyński odmówił udziału w pracach tego rządu ${ }^{55}$. Dnia 29 listopada 1944 r. Prezydent RP powierzył mianowanemu w tym dniu prof. Władysławowi Folkierskiemu na ministra prac kongresowych funkcję kierownika (nie ministra) Ministerstwa WRiOP ${ }^{56}$. Z pracy w Ministerstwie odszedł niebawem prof. Skąpski. Poszerzył się znacznie zakres zadań prof. Sulimirskiego jako kierownika Działu Ogólnego. W kwietniu 1945 r. został on sekretarzem generalnym Ministerstwa WRiOP, na jego barkach spoczęły wszelkie robocze sprawy związane z funkcjonowaniem szkolnictwa polskiego na obczyźnie ${ }^{57}$.

Funkcję tę przypadło mu pełnić w niezwykle trudnym okresie rządu RP na uchodźstwie. Od samego początku rok ten zapowiadał się bowiem jako bardzo ciężki pod względem finansowym, następowały drastyczne ograniczenia w wydatkach na oświatę. 17 kwietnia Rada Ministrów RP podjęła uchwałę, w której m.in. zapisano:

Należy obniżyć normy wynagrodzenia za wykłady w szkołach i na kursach organizowanych przez władze państwowe i instytucje subwencjonowane [...] Nowe szkoty i kursy moga być organizowane w każdym poszczególnym wypadku, jedynie na podstawie uchwały Rady Ministrów, nawet wtedy, gdy zostały przewidziane w obowiazującym preliminarzu budżetowym. [...] Wszelka działalność wydawnicza własna i subwencjonowana winna być ograniczona ${ }^{58}$.

Były też i inne ograniczenia dotyczące funkcjonowania całości życia emigracyjnego, które pośrednio wpływały na sytuację szkolnictwa.

Budżet na rok 1945 nie został wdrożony w życie. Realizowano wydatki w okresach miesięcznych, określanych na podstawie budżetu z 1944 r. Sytuacja taka trwała do cofnięcia uznania rządowi polskiemu przez Wielką Brytanię w dniu 5 lipca 1945 r. ${ }^{59}$. Fakty te bardzo komplikowały pracę kierownika Działu Ogólnego, a następnie sekretarza generalnego i wymagały dużego wysiłku organizacyjnego, aby zapewnić płynność pracy resortu i podległych mu placówek na kilku kontynentach, przy bardzo ograniczonej łączności i prawie braku regularnej komunikacji.

Mimo tak trudnych warunków finansowych i ciągle pogarszającej się sytuacji politycznej Polski, Tadeusz Sulimirski nieustannie wspierał nowe inicjatywy oświatowe na uchodźstwie. Wobec coraz bardziej wyraziście rysującej się na obczyźnie i w kraju trudnej do rozwiązania kwestii braku nauczycieli, zainspirował dr. Jana Konopnickiego do opracowania projektu utworzenia dużego zakładu kształcenia nauczycieli na uchodź-

${ }_{55}$ R. Gajewski, op. cit., s. 259.

56 Dział urzędowy. Zwolnienia i mianowania ministrów, DzURP, 30 listopada 1944, nr 14, część II.

57 W. Chmielewski, Przygotowanie kadr..., op. cit., s. 29.

58 IPMS, MWRiOP, sygn. A.19. III/58, Odpis. Uchwała Rady Ministrów z dnia 17 kwietnia 1945 r. w sprawie ograniczenia wydatków budżetowych.

59 T. Sulimirski, Fundusz Kultury Narodowej, „Nauka Polska na Obczyźnie 1939-1960” 1961, z. 3, s. 55. 
stwie. Sugestię tę Konopnicki przyjął i rozwinął, myślał zresztą o tej sprawie także od dwóch miesięcy. Zaproponował więc Sulimirskiemu 12 stycznia 1945 r. wstępną koncepcję uruchomienia Ośrodka Pedagogicznego w Afryce. W jego skład w myśl pierwotnych założeń miało wejść trzyletnie liceum pedagogiczne, jednoroczny kurs pedagogiczny dla starszych absolwentów gimnazjum czteroletniego i kurs korespondencyjny dla czynnych a niewykwalifikowanych nauczycieli szkół powszechnych. Tak zorganizowany zakład kształcenia nauczycieli zamierzał Konopnicki prowadzić w Afryce w gronie 7-8 nauczycieli o wysokich kwalifikacjach pedagogicznych. Osoby te miałyby również:

a) opracowania programów dla wszystkiego rodzaju kursów, b) ew[entualnego] opracowania, czy przettumaczenia podręczników pedagogicznych, c) wydawania Tygodnika Pedagogicznego,

d) przeszkalania czynnych, kwalifikowanych i niekwalifikowanych nauczycieli $w$ Afryce, e) przygotowania i przystosowania do dzieci polskich różnego rodzaju testów umystowych (inteligencji i wiadomości). Badania dzieci polskich [w różnych osiedlach rozsianych w Afryce przyp. W.Ch.] na duża skale można by przeprowadzać równocześnie z doszkalaniem nauczycieli na krótkich kursach, tak, że jeden wyjazd mógtby być wykorzystany dla obu celów ${ }^{60}$.

Praktyczną realizację tego projektu Jan Konopnicki proponował wdrażać w życie już od czerwca 1945 r. Zwracał się też prośbą do „Tadzia” o pomoc w wydaniu swojej książki oraz publikacji przetłumaczonej z języka angielskiego na język polski ${ }^{61}$. Koncepcja ta przybrała za wiedzą i akceptacją prof. Tadeusza Sulimirskiego znacznie rozbudowany kształt $^{62}$. Pozytywnie odniósł się do inicjatywy uruchomienia na wiosnę 1945 r. Wyższego Kursu Nauczycielskiego Londynie Wielkiej Brytanii. Na podkreślenie zasługuje fakt, że absolwenci tego WKN otrzymali świadectwa wydane na podstawie rozporządzenia prezydenta RP. Wystąpił z propozycją stworzenia dla byłych uczniów liceów pedagogicznych, przebywających na Wyspach Brytyjskich, możliwości dokończenia nauki w tego typu szkołach w projektowanym trzyletnim Liceum Pedagogicznym w Glasgow ${ }^{63}$. W celu pozyskania kandydatów do tej szkoły nauczycielskiej nawiązał kontakt z dowództwem wojskowym. Mimo wielu starań inicjatywa ta nie przyniosła rezultatu z powodu braku finansów.

W grudniu 1945 r. uzyskał jednak kredyt od władz brytyjskich na szkolenie nauczycieli w zakresie podnoszenia kwalifikacji zawodowych. Przyznane środki finansowe postanowił odpowiednio wykorzystać i zorganizować w styczniu i w lutym 1946 r. dwumiesięczny kurs dla kandydatów na inspektorów i podinspektorów szkolnych,

${ }^{60}$ IPSM, Kol. 548/13, Pismo J. Konopnickiego z 12 stycznia 1945 roku do T. Sulimirskiego, zawierające wstępną koncepcję Ośrodka Pedagogicznego w Afryce.

61 Ibidem.

62 W. Chmielewski, Przygotowanie kadr..., op. cit., s. 123-125.

${ }^{63}$ Ibidem, s. 130, 131. 
rekrutujących się spośród słuchaczy Wyższego Kursu Nauczycielskiego w Londynie, służących w polskich jednostkach wojskowych na Wyspach Brytyjskich ${ }^{64}$.

Nie sposób wymienić wszystkich inicjatyw prof. Sulimirskiego, z którymi występował podczas pracy w instytucjach polskich władzach oświatowych na uchodźstwie. Miał ich wiele, zawsze przepełnione były wielką troską o wychowanie młodego pokolenia na dobrych obywateli Polski. Zawsze miały na uwadze dobro każdego Polaka na obczyźnie. Swoim zaangażowaniem, starannością i dokładnością wykonywanej pracy budził szacunek i uznanie całej społeczności uchodźczej.

\section{Kierowanie Działem Oświaty ITC}

Wydarzeniem przełomowym w życiu polskiego uchodźstwa było cofnięcie uznania rządowi RP w Londynie przez Wielką Brytanię w dniu 5 lipca 1945 r. oraz w podobnym czasie przez inne państwa zachodnie wraz ze Stanami Zjednoczonymi Ameryki Północnej. Ten brzemienny w skutkach dla Polski akt zmienił sytuację Polaków na obczyźnie.

Cofnięcie uznania Rzadowi RP - pisał prof. Tadeusz Sulimirski - zaważyło ciężko na sprawach oświatowych i kulturalnych uchodźstwa polskiego. Wprawdzie Rząd RP nie przestat istnieć na skutek cofnięcia uznania ze strony dotychczasowych sojuszników, nie miat on już jednak warunków do rozwijania działalności w takim zakresie, jak poprzednio. Działalność Ministra WRiOP musiała siła rzeczy, ograniczyć się tylko do prób koordynacji różnych niezależnych poczynań polskich ${ }^{65}$.

Rząd brytyjski dążył do szybkiego i sprawnego zlikwidowania struktur organizacyjnych uchodźstwa polskiego w Wielkiej Brytanii, a przede wszystkim aparatu administracyjnego rządu polskiego. Zamierzał też doprowadzić do zaprzestania działalności podległych mu instytucji edukacyjnych, naukowych, społeczno-kulturalnych i opiekuńczo-wychowawczych. Realizacja tego celu przebiegała w ciągle narastającej, nieprzychylnej atmosferze społeczeństwa brytyjskiego wobec uchodźców, na których wywierano nacisk, aby po zakończonej wojnie opuszczali Wyspy i wracali do Polski. Tymczasem obywatele polscy, wywodzący się w dużej części spośród mieszkańców kresów wschodnich II Rzeczypospolitej, pozbawionych stron ojczystych, nie chcieli wracać do Polski rządzonej przez niewielką grupę ludzi realizujących politykę Związku Radzieckiego. Wykonanie wymienionych zadań, a zwłaszcza kwestię likwidacji zobowiązań finansowych polskiego rządu miał przeprowadzić nowo utworzony 7 lipca 1945 r. Tymczasowy Komitet Skarbu dla Spraw Polskich (The Interim Treasury Committee for Polish Questions), znany pod powszechnie używanym skrótem (ITC). Przewodniczącym ITC został podsekretarz stanu

\footnotetext{
${ }^{64}$ IPMS, MWRiOP, sygn. A.19.II/29, Pisma T. Sulimirskiego z 17 grudnia do Sztabu Głównego w Londynie w sprawie urlopowania 6 oficerów i 9 podoficerów nauczycieli na kurs.

${ }^{65}$ T. Sulimirski, Nauka polska na obczyźnie 1939-1954, „Nauka Polska na Obczyźnie” 1955, z. 1, s. 6-7.
} 
w Ministerstwie Skarbu rządu Wielkiej Brytanii Wilfrid Eady. Głównym Polskim Przedstawicielem mianowano ambasadora Edwarda Raczyńskiego, którego Brytyjczycy zawsze darzyli dużym zaufaniem. Stanowisko głównego administratora pełnili kolejno: David B. Pitbla i Henry H. Eggers z Ministerstwa Skarbu. Kierownikiem biura Głównego Polskiego Przedstawiciela był Stanisław W. J. Szydłowski. Kierownikami działów zostali: Dział Finansowy - J. Łuba, Dział Oświaty prof. T. Sulimirski, Dział Pracy i Opieki W. Mohl, Dział Kontroli - S. Okoniewski ${ }^{66}$. 16 września 1946 r. Edward Raczyński powołał jeszcze do życia Dział Emigracyjny ${ }^{67}$.

O utworzeniu ITC kierownik Działu Oświaty poinformował podległe Ministerstwu WRiOP instytucje edukacyjne. Oznajmił, że ITC zamierza utrzymać na pewien czas wszystkie czynne obecnie placówki oświatowe w Zjednoczonym Królestwie. Obecnie tocza się rozmowy zmierzające do ustalenia sposobu finansowania tych placówek ${ }^{68}$. Zapewnił też, że podjęto wszelkie starania, aby wypłata wynagrodzeń i innych świadczeń za pracę dokonana zostanie w sierpniu w normalnym terminie. Zaapelował do kierowników instytucji edukacyjnych, personelu wykładajacego i słuchaczy o wzięcie pod uwage obecnych wyjątkowych warunków, zachowanie catkowitego spokoju i normalny, niezakłócony tok prac ${ }^{69}$.

Zadania Działu Oświaty były obszerne i obejmowały takie zagadnienia, jak:

- sprawowanie nadzoru pedagogicznego nad wszystkimi uchodźczymi instytucjami edukacyjnymi,

- mianowanie w porozumieniu z władzami wojskowymi dyrektorów i kierowników przedszkoli oraz wszystkich typów szkół,

- udzielanie pozwoleń na organizację i prowadzenie placówek oświatowo-wychowawczych, zatwierdzanie ich statutów i programów nauczania,

- powoływanie i odwoływanie komisji egzaminacyjnych,

- określanie kwalifikacji i uprawnień absolwentów szkół i kursów,

- nadzór nad wydawaniem świadectw szkolnych,

- finansowanie nadzorowanych przedszkoli i szkół oraz udzielanie stypendiów studentom polskim na uczelniach zagranicznych i polskich wydziałach,

- finansowanie działalności naukowej, artystycznej, praktyk, staży i nauki języka angielskiego ${ }^{70}$.

Nowo utworzony Działu Oświaty ITC (Educational Branch of the ITC), nazywany też dość powszechnie Wydziałem Oświatowym lub Wydziałem Oświaty posiadał rozbu-

${ }^{66}$ S. Szydłowski, Studia wyższe Polaków w Wielkiej Brytanii, „Nauka Polska na Obczyźnie 1939-1960” 1961, z. 3, s. 37.

${ }^{67}$ IPMS, MWRiOP, sygn. A.19.III/68, Okólnik Nr 36 w sprawie utworzenia i organizacji Działu Emigracyjnego Tymczasowego Komitetu do Spraw Polskich. Londyn 16 września 1946 r.

${ }^{68}$ Ibidem, Pismo T. Sulimirskiego z 19 lipca 1945 roku, rozesłane według rozdzielnika.

${ }^{69}$ Ibidem.

70 T. Radzik, Brytyjska pomoc edukacyjna, w: Mobilizacja uchodźstwa do walki politycznej 1945-1990, Polskie Towarzystwo Naukowe na Obczyźnie, Londyn 1995, s. 354-355. 
dowaną strukturę. We wrześniu 1945 r. obejmował on: Wydział Szkolnictwa Wyższego (kierownik dr Marian Książkiewicz), Wydział Szkolnictwa Ogólnokształcącego (dr Franciszek Lenczowski), Wydział Szkolnictwa Zawodowego (Władysław Jędral), Wydział Szkolnictwa poza Wielką Brytanią (dr Ignacy Wieniewski), Wydział Wyznań Religijnych (Wiktor Piotrowicz), Wydział Prawno-Organizacyjny (dr Tadeusz Bugayski), Wydział Budżetowy (Bohdan Piechowski), Wydział Wydawniczy (Herman Wellik), Wydział Oświaty Pozaszkolnej i Organizacji Młodzieżowych (Władysław Donigiewicz), Wydział Szkolnictwa Administracyjnego (dr Mieczysław Seydlitz) Biblioteka (mgr Maria Danilewicz), Kancelaria Ogólna (dr Zdzisław Stabrawa) ${ }^{71}$. Ta organizacja Działu Oświaty przetrwała zaledwie kilka miesięcy. W związku ze zmieniającą się sytuacją uchodźstwa i zamykania, zwłaszcza w dominiach, wielu instytucji edukacyjnych, kilka wydziałów uległo likwidacji, a ich zakres czynności przejęły te wydziały, które nadal prowadziły działalność. Zarządzeniem z dnia 18 maja 1946 r. wprowadzona została nowa struktura organizacyjna Działu Oświaty. Dokonano też niezbędnych zmian kadrowych, wynikających również z faktu powrotu niektórych osób do kraju ${ }^{72}$. Pierwszym zastępcą Sulimirskiego został nadal dr Mieczysław Giergielewicz, drugim - mgr Witold Łęgowski. W skład Działu Oświaty wchodziły: Wydział Ogólny - sprawy personalne, prawne i organizacyjne (dr Tadeusz Bugayski), Wydział Szkolnictwa Wyższego - polskie szkoły wyższe w Wielkiej Brytanii, lektoraty języka polskiego, pomoc studentom uczonych, współpraca z instytucjami i towarzystwami naukowymi oraz artystycznymi, pisarzom, artystom i innym (kierownik dr Marian Książkiewicz, a później prof. Bogdan Zaborski); Wydział Nauczania i Wychowania Ogólnego - przedszkola, szkolnictwo powszechne i średnie ogólnokształcące, organizacja i nadzorowanie placówek oświaty pozaszkolnej dla dorosłych, organizacje młodzieżowe (dr Jan Dąbrowski); Wydział Szkolnictwa Zawodowego wszystkie typy szkolnictwa zawodowego (Władysław Jędral); Wydział Budżetowy sprawy budżetowo-rachunkowe, administracyjno-gospodarcze, kontroluje wydatki Działu Oświaty i placówek (Bohdan Piechowski); Wydział Wydawniczy - wydawanie i zakup książek i podręczników szkolnych, skryptów i pomocy naukowych, prowadzi składnicę książek i innych pomocy szkolnych (Herman Wellik); Biblioteka - gromadzenie i katalogowanie dzieł naukowych, podręczników szkolnych i innych książek oraz rękopisy, czasopisma, prowadzenie wypożyczalni książek i czytelni (mgr Maria Danilewicz); Kancelaria Ogólna - prawidłowy obieg wewnętrzny przychodzących pism, prowadzenie korespondencji, archiwum, sporządza maszynopisy (mgr Marian Wlekliński) ${ }^{73}$. Szeroki zakres czynności poszczególnych wydziałów dowodzi, że Dział Oświaty ITC wypełniał

${ }^{71}$ IPMS, MWRiOP, sygn. 19. III/67, Okólnik Nr w sprawie organizacji Działu Oświaty Tymczasowego Komitetu Treasury do Spraw Polskich, Londyn, wrzesien 1945 rok.

${ }_{72}$ Ibidem, sygn. 19. III/6. Zarządzenie T. Sulimirskiego z 22 listopada 1945 roku o zatrudnieniu dotychczasowych kierowników wydziałów M. Seydlitza i W. Piotrowicza na niższych stanowiskach w innych wydziałach Działu Oświaty.

${ }^{73}$ Ibidem, sygn. 19. III/68, Okólnik Nr 33 w sprawie organizacji Działu Oświaty Tymczasowego Komitetu Treasury do Spraw Polskich, Londyn, 18 maja 1946 rok. 
wiele ważnych zadań na rzecz życia kulturalno-oświatowego w bardzo trudnym okresie. Jego kompetencje w sensie podejmowanych problemów i konkretnych tematów niewiele ustępowały zadaniom stawianym przed resortem oświaty. Inny był jednak jego podstawowy cel działania, jak również charakteryzował go brak możliwości podejmowania inicjatyw o charakterze aktów prawnych. Dział Oświaty zatrudniał 61 pracowników. W ogromnej większości byli oni dotychczas zatrudnieni jako dobrzy fachowcy w Ministerstwie WRiOP ${ }^{74}$. Dzięki temu wiele osób niewystarczająco znających język angielskich uchronionych zostało od utraty źródła utrzymania. Zastępcą prof. Tadeusza Sulimirskiego został dr Mieczysław Giergielewicz. Strukturę Działu Oświaty ITC przedstawiają aneksy nr 2 i 3. Z kolei delegatury Ministerstwa WRiOP i podległe im polskie placówki oświatowo-wychowawcze poza Wielką Brytanią zarządzane przez krótki okres przez ITC, przeszły na finansowanie przez Administrację Narodów Zjednoczonych do Spraw Pomocy i Odbudowy (United Nations Relief and Reconstruction Administration - UNRRA), a następnie Międzynarodową Organizację Uchodźców (International Refugee Organization - IRO ${ }^{75}$ ). Dotyczyło to polskich instytucji oświatowych (przedszkoli, szkół, świetlic i internatów) w Iranie (Delegatura Teheran), Indiach (Bombaj), w Afryce (Nairobi - Kenia) i na Bliskim Wschodzie (Jerozolima - Palestyna). Szkoły polskie w Meksyku (Santa Rosa) przeszły pod opiekę Stanów Zjednoczony Ameryki Północnej, a w Nowej Zelandii (Pahiatua) - tamtejszego rządu. Wszędzie jednak, zwłaszcza $\mathrm{w}$ początkowym okresie działalności ITC wiele istotnych decyzji podejmowano w konsultacji i po zajęciu stanowiska w każdej ważnej sprawie przez prof. Tadeusza Sulimirskiego oraz skupiony wokół niego zespół ludzi ${ }^{76}$.

Generalnie miała obowiązywać zasada, zgodnie z koncepcją Brytyjczyków, że Dział Oświaty wspiera dokończenie danego rodzaju działalności, a nie inicjowanie i rozwijanie nowych projektów. Zasada ta, m.in. dzięki kreatywności prof. Sulimirskiego i wielu jego współpracowników nie zawsze była przestrzegana. Stanowisko to było rezultatem troski o utrzymanie jak najdłużej stanu posiadania polskiego szkolnictwa, chronienia go od pochopnej likwidacji w Wielkiej Brytanii i jej dominiach, a przede wszystkim wynikało z postawy patriotycznej uchodźstwa i niezachwianego przekonania, że oddanie Polski decyzją mocarstw zachodnich w orbitę wpływów Związku Radzieckiego bardzo skrzywdziło ojczyznę i jej obywateli. Nie najlepsze nastroje wśród Polaków w Wielkiej Brytanii pogarszał fakt, że aby przetrwać i dostosować się do życia na emigracji, w coraz więk-

\footnotetext{
${ }^{74}$ Ibidem, sygn. MWRiOP, sygn. A. 19. III/68, Lista pracowników Działu Oświaty, 2 marca 1946 rok.

${ }^{75}$ T. Sulimirski, Nauka polska..., op. cit., s. 6.

${ }^{76}$ IPMS, MWRiOP, sygn. A. 19. III/13, Pismo T. Sulimirskiego z 9 października 1945 roku do F. Soboty w sprawie rozwiązania jego stosunku służbowego z Ministerstwem WRiOP, jako delegata tegoż resortu w Meksyku; tamże, Pismo T. Sulimirskiego z 27 marca 1946 roku do F. Soboty w sprawie zabronienia używania przez niego nazwy delegata Ministerstwa WRiOP w Meksyku i stosowania nadruków z nazwą Delegatury w prowadzonej korespondencji; Archiwum Akt Nowych w Warszawie, zespół: Poselstwo RP w Meksyku, sygn. 179. Pismo T. Sulimirskiego z 9 lipca 1946 roku do H. Stebelskiego w sprawie kontroli finansowej byłej Delegatury Ministerstwa WRiOP w Meksyku. T. Sulimirski przesłał też instrukcję w sprawie rozliczenia działalności finansowej byłej Delegatury.
} 
szym stopniu musieli uczyć się języka angielskiego. Od końca września 1946 r. strona brytyjska w ITC, a w ślad za nią Główny Polski Przedstawiciel, ambasador Edward Raczyński zalecili, aby wszelką korespondencję służbową prowadzić $w$ granicach możliwości w języku polskim. Bezwarunkowo należało korespondować w języku angielskim na temat wszystkich spraw finansowych jednostek organizacyjnych i instytucji edukacyjnych $^{77}$.

Nie zważając na piętrzące się trudności międzynarodowe i niesprzyjającą atmosferę wytwarzaną wokół środowiska polskiego, prof. Tadeusz Sulimirski niezwykle ofiarnie angażował się zarówno w sprawy zasadnicze, wielkie, jak i pozornie niemające znaczenia, ale ważne po cofnięciu uznania polskiemu rządowi, dla umacniania świadomości i ducha polskości, np. na wniosek Jana Konopnickiego spowodował, aby polskie świadectwa słuchaczy Studium Pedagogicznego w Edynburgu z roku akademickiego 1944/45, które miały charakter oficjalny, również i dla władz Uniwersytetu w Edynburgu, były wydane przez Ministerstwo WRiOP, mimo że widniała na nich data 31 lipca 1945 r., a więc już po cofnięciu uznania rządowi polskiemu na uchodźstwie. Do niego też zwracano się w wielu sprawach wymagających zręcznych i skutecznych interwencji (np. wypłata należności autorom $\mathrm{z}$ tytułu opracowania programu nauczania dla liceum pedagogicznego $)^{78}$. Pisma $\mathrm{z}$ jego podpisem widnieją $\mathrm{w}$ dokumentacji archiwalnej wszystkich polskich osiedli, znajdujących się na kilku kontynentach, w których prowadzono działalność edukacyjną. $Z$ racji pełnionej funkcji i posiadanego autorytetu zajmował często stanowisko w rozstrzyganiu lokalnych problemów, zwykłych konfliktów międzyludzkich, czy też kwestii kwalifikacji nauczycielskich, przydatnych do pracy w danym typie szkó ${ }^{79}$.

Kierując Działem Oświaty ITC nie tylko troszczył się o istniejące do tej pory w Wielkiej Brytanii polskie instytucje oświatowo-kulturalne, ale także podejmował starania o zorganizowanie nowych form edukacji. Przykładem takiego działania może być uzyskanie od władz brytyjskich kredytu na zorganizowanie dwumiesięcznego kursu dla przyszłych inspektorów i podinspektorów szkolnych, będących absolwentami Wyższego Kursu Nauczycielskiego w Londynie. Kontynuował podjęte przed cofnięciem uznania rządowi polskiemu inicjatywy na rzecz kształcenia i podwyższania kwalifikacji nauczycieli. Pojawiła się koncepcja utworzenia liceum pedagogicznego w Crieff, uruchomiono drugi WKN i podjęto przygotowania do otwarcia Specjalnego Kursu Nauczycielskiego, który swoją działalność rozwinął już w innym systemie zarządzania polskim szkolnictwem ${ }^{80}$.

\footnotetext{
${ }^{77}$ Ibidem, sygn. A. 19. III/68, Pismo T. Sulimirskiego z 14 października 1945 roku, rozesłane według rozdzielnika.

${ }_{78}^{7 P M S, ~ K o l . ~ 548 / 13, ~ P i s m o ~ J . ~ K o n o p n i c k i e g o ~ z ~} 26$ lipca 1945 roku do T. Sulimirskiego w sprawach bieżących; W. Chmielewski, Przygotowanie kadr.., op. cit., s. 184.

${ }^{79}$ IPMS, MWRiOP, sygn. A. 19.III/17, Pismo T. Sulimirskiego z 8 grudnia 1945 roku do ks. M. Wilniewczyca w sprawie zatrudnienia Jadwigi Żerebeckiej.

${ }^{80}$ W. Chmielewski, Przygotowanie kadr..., op. cit., 132-134.
} 
Wiele uwagi poświęcał poprawie sytuacji materialnej studentów $\mathrm{w}$ trudnej dla polskiego uchodźstwa 2. poł. 1945 r. i w latach następnych. Wyrazem tego było przewodniczenie Komisji Stypendialnej Zrzeszenia Profesorów i Docentów Polskich Szkół Akademickich w Wielkiej Brytanii, która kierowała Funduszem Stypendialnym tej organizacji. Fundusz wspierał młodzież urlopowaną z Polskich Sił Zbrojnych, która studiowała na uczelniach brytyjskich. Działalność Tadeusza Sulimirskiego w tej dziedzinie przyniosła znakomite efekty, znacznie wykraczające poza pierwotnie zarysowaną koncepcję $e^{81}$.

Doprowadził do wyłonienia Komisji w Sprawie Studiów Akademickich z udziałem ówczesnego kierownika Wydziału Szkolnictwa Wyższego Działu Oświaty prof. Bohdana Zaborskiego. Komisja podjęła wysiłek koordynowania, w miarę skromnych możliwości, trudnego zadania zapewnienia środków utrzymania z różnych źródeł (ITC, UNRRA, IRO, Fundacja Rockfellera, Fundusz Kultury Narodowej, fundacje zagraniczne i polskie organizacje, np. Polska YMCA, PCK) ${ }^{82}$.

W trosce o prawidłowe zagospodarowanie czasu wolnego i rozwój społeczno-kulturalny i oświatowy rozmieszczanych osób w hostelach opracowano w Dziale Oświaty Wytyczne w sprawie szkolnictwa i oświaty pozaszkolnej na uchodźstwie ${ }^{83}$.

Na początku 1946 r., gdy okazało się, że ogromna większość obywateli polskich, znajdujących się w Wielkiej Brytanii, jej dominiach i we Włoszech nie chce wrócić do kraju rządzonego przez ludzi związanych Kremlem, przewidując dłuższy, trudny do określenia w czasie, ich pobyt w Wielkiej Brytanii, kierowany przez Władysława Donigniewicza Wydział Oświaty Pozaszkolnej i Organizacji Młodzieżowych, istniejący w pierwszym roku funkcjonowania Działu Oświaty ITC, opracował w pierwszym kwartale 1946 r. Wytyczne w sprawie szkolnictwa i oświaty pozaszkolnej na uchodźstwie. W dokumencie przedstawiono cele i zadania szkolnictwa polskiego i oświaty dla dorosłych w zakresie utrzymania związków uchodźstwa z kulturą ojczystą. Zawarte w nich dezyderaty sformułowano w taki sposób, aby ich realizacja była zgodna z potrzebami edukacyjnymi i asymilacyjnymi zarówno społeczności uchodźczej na obczyźnie, jak i gospodarki krajowej. Uznano za słuszne, że:

dla wypetnienia swych zadań wychowawczych i kulturalnych uchodźstwo winno wytworzyć, zabezpieczyć i utrzymać planowy system wychowania i szkolenia, obejmujacy:

a) zapewnienie opieki rodzinie polskiej na zasadach wzajemnej pomocy, zwłaszcza w zakresie pielegnowania języka i kultury ojczystej,

b) utrzymanie przedszkoli istniejacych oraz tworzenie i popieranie nowych,

c) prowadzenie petnowartościowych polskich szkót powszechnych i średnich ogólnokształcących,

d) organizowanie zakładów kształcenia nauczycieli,

${ }^{81}$ T. Sulimirski, Nauka polska..., op. cit., s. 7.

${ }^{82}$ IPMS, MWRiOP, sygn. A. 19 III/44, Pismo T. Sulimirskiego z 23 lipca 1946 roku do B. Zaborskiego na temat posiedzenia Komisji w Sprawie Studiów Akademickich; tamże. Projekt. Wnioski Komisji.

${ }^{83}$ Ibidem, sygn. A. 19. VI/20, Wytyczne w sprawie szkolnictwa i oświaty pozaszkolnej na uchodźstwie, Londyn 1946. 
e) organizację wykształcenia zawodowego na różnych szczeblach w szkołach własnych lub obcych,

f) zapewnienie i umożliwienie nauki o życiu i kulturze polskiej osobom uczęszczającym do uczelni obcych za pomoca systematycznych kursów i stałej opieki kulturalnej oraz udostępnienia składania odpowiednich egzaminów,

g) wyzyskania form nauczania korespondencyjnego, gdziekolwiek nauka bezpośrednia nie jest możliwa

h) stosowanie form oświaty pozaszkolnej $w$ możliwie szerokim zakresie,

i) umożliwienie jednostkom zdolniejszym studiów wyższych: zachęcanie do pracy naukowej $w$ zakresie kultury polskiej oraz tworzenie tam, gdzie warunki na to pozwola statego studium $w$ tej dziedzinie $e^{84}$.

Proponowano, aby naukę w szkołach prowadzić w języku polskim, ale równocześnie położyć nacisk na opanowanie języka angielskiego, aby w ten sposób umożliwić młodzieży uchodźczej możliwość kontynuowania nauki w szkołach brytyjskich. Szczególną uwagę proponowano zwrócić na przyswojenie słownictwa technicznego. Zadaniem wszelkiej działalności edukacyjnej na obczyźnie powinno być zachowanie i chronienie kultury polskiej przed wypaczeniem i ukazywanie jej cech rodzimych i zachodnich.

W zakresie krzewienia kultury polskiej zalecano, aby przyjąć za zasadę, że powinna ona zawsze opierać się na etyce chrześcijańskiej i wielowiekowym dorobku antycznej Grecji oraz Rzymu. Należy dążyć do ścisłej więzi z Zachodem, a zwłaszcza z narodami anglosaskimi i romańskimi. Sugerowano wprowadzenie do szkół w ramach przedmiotu „zagadnienia życia współczesnego" wiadomości o Polsce nowoczesnej, a zwłaszcza o latach 1918-1939 oraz jej aktualnej sytuacji politycznej, społecznej, gospodarczej i kulturalnej. Proponowano, aby młodzieży studiującej na polskich wydziałach technicznych i medycznych na emigracji zorganizować wykłady z kultury polskiej.

Zalecono tworzenie na poziomie szkół wyższych, jeśli tylko warunki na to pozwolą, ośrodków nauczania kultury polskiej. Uznano, że mogłyby one przybierać formę studiów humanistycznych, obejmującymi takie podstawowe przedmioty, jak: język, literatura i kultura polska lub studiów kultury polskiej, gdzie obok przedmiotów ściśle polonistycznych wykładana będzie historia, filozofia, kultura klasyczna.

W zaistniałych warunkach życia emigracji polskiej dużą uwagę zwrócono na szkolnictwo zawodowe. Jego rola miała polegać na przygotowaniu młodego pokolenia Polaków do samodzielnej pracy zawodowej, tak na obczyźnie, jak i po ewentualnym powrocie do kraju. Utrzymując dotychczas istniejące szkoły zawodowe, zalecano otwieranie nowych, dostosowanych do rzeczywistych i aktualnych potrzeb uchodźstwa, rozwijających się gałęzi przemysłu w Stanach Zjednoczony i na zachodzie Europy oraz warunków gospodarczych w kraju. Nawoływano do organizowania kursów krótkoterminowych o tematyce zawodowej i odbywania praktyk w nowoczesnych zakładach przemysłowych. Uznano, że:

\footnotetext{
84 Ibidem.
} 
należy zapewnić uczniom opanowanie obcego słownictwa zawodowego oraz korzystania z miejscowych pomocy naukowych, urzadzeń do zajęć praktycznych przez:

a) organizowanie kursów uzupetniających,

b) wprowadzenie $w$ wypadkach koniecznych równolegle z lekcjami polskimi nauki pewnych przedmiotów zawodowych w języku niepolskim,

c) odpowiedni program nauki języka obcego,

d) zacieśnienie wspótpracy z miejscowymi szkołami, zakładami przemysłowo - handlowymi i organizacjami zawodowymi ${ }^{85}$.

Przewidywano także korespondencyjne szkolenie zawodowe dla młodzieży pozbawionej systematycznej edukacji szkolnej oraz dla osób dorosłych, pragnących podwyższyć lub zmienić posiadane kwalifikacje zawodowe.

Szczególnie szeroko rozbudowano w wytycznych zagadnienie oświaty pozaszkolnej na obczyźnie. Jej podstawowym celem było włączenie całego społeczeństwa na emigracji w uczestnictwo w zbiorowym życiu cywilizacyjnym i kulturalnym, przekazanie mu wartości i cech charakterystycznych dla narodu polskiego, wynikających z jego dziejów i dorobku kulturalnego, przede wszystkim zaś zaszczepienie w nim wartości uniwersalnych. Oświata pozaszkolna powinna być prowadzona w domach ludowych, bibliotekach, czytelniach, klubach, świetlicach, ogniskach oświatowych, izbach harcerskich, placówkach upowszechniania kultury fizycznej, teatrach, ośrodkach widowiskowych i muzycznych. W skupiskach polskich, gdzie nie będzie tych instytucji kulturalno-oświatowych, czy też szkół, należy zwrócić szczególną uwagę na wychowanie przedszkolne oraz prowadzenie dla dzieci i młodzieży uczęszczającej do szkół niepolskich nauki religii, języka polskiego, historii, literatury i geografii. Większe ośrodki polskie powinny wydawać czasopisma, tworzyć chóry i organizacje śpiewacze. Należy organizować i uaktywniać pracę organizacji młodzieżowych, a zwłaszcza harcerstwa. Nakreślone wytyczne rozwoju oświaty pozaszkolnej wykraczały znacznie poza cele i zadania ITC, i z pewnością nie zmierzały do stopniowego ograniczania działalności polskiego środowiska uchodźczego ${ }^{86}$.

Tymczasem zmieniająca się sytuacja międzynarodowa w 1946 r., a przede wszystkim pogorszenie się stosunków państw zachodnich z umacniającym swoją pozycję na świecie Związkiem Radzieckim wpłynęło dodatnio na poprawę sytuacji Polaków w Wielkiej Brytanii. Najpierw rząd Zjednoczonego Królestwa Wielkiej Brytanii, a później jego społeczeństwo ze zrozumieniem zaczęło się odnosić do niechęci powrotu Polaków do swojej ojczyzny, będącej pod przemożnym wpływem wschodniego sąsiada ${ }^{87}$. Rząd brytyjski podjął się, niespotykanego dotychczas w dziejach Zjednoczonego Królestwa podobnego przedsięwzięcia, a mianowicie, sprowadzenia z Włoch na Wyspy 2 Korpusu Polskiego wraz z rodzinami i tzw. dependenents - osobami będącymi na utrzymaniu (według źródeł

\footnotetext{
85 Ibidem.

${ }^{86}$ Ibidem.

87 T. Sulimirski, Nauka polska..., op. cit., s. 6-7.
} 
brytyjskich około 160 tys. osób $)^{88}$. Zapadła też decyzja o przenoszeniu wraz z wojskiem szkół nadzorowanych przez 2 Korpus ${ }^{89}$.

Już po kilku tygodniach rozpoczęcia akcji transportowania jednostek 2 Korpusu do Wielkiej Brytanii, Dział Oświaty ITC podjął kroki zmierzające do jak najlepszego przyjęcia cywilnych i wojskowych instytucji edukacyjnych. Z myślą o pracy kulturalno-oświatowej wśród obywateli polskich, pozostających w Wielkiej Brytanii i jej dominiach ${ }^{90}$, mających być stopniowo zgrupowanych w kilkuset hostelach (obozach) pod opieką Polskiego Korpusu Przysposobienia i Rozmieszczenia, opracowano Projekt organizacji powszechnej akcji kulturalno-oświatowej dla żotnierzy II Korpusu w Wielkiej Brytanii ${ }^{91}$.

Prof. Sulimirski zwrócił się do ppłk prof. Jerzego Alexandrowicza, kierującego Wydziałem Oświaty 2 Korpusu o nadesłanie dokładnej informacji na temat szkół, które rzeczywiście zostaną przeniesione na Wyspy Brytyjskie i stanu ich zaopatrzenia w pomoce dydaktyczne i przybory szkolne ${ }^{92}$. Prowadził też rozmowy wspólnie z Edwardem Raczyńskim i prof. Zaborowskim z delegacją studentów polskich we Włoszech, pod kierownictwem Edwarda Franciszka Szczepanika, będących pod opieką 2 Korpusu, w sprawie ich przyjazdu do Wielkiej Brytanii, w celu kontynuowania studiów ${ }^{93}$.

Przybycie dużej liczby obywateli polskich na Wyspy Brytyjskie w ramach 2 Korpusu Polskiego spowodowało dalsze sprecyzowanie polityki oświatowej na najbliższy okres, prowadzonej przez władze brytyjskie wobec uchodźców. Znalazło to swój wyraz w wytycznych zawartych w liście z 23 sierpnia 1946 r., które przysłał Henry H. Eggers, reprezentujący Ministerstwo Skarbu i zarazem ITC ze strony brytyjskiej bezpośrednio na ręce prof. Tadeusza Sulimirskiego ${ }^{94}$.

Począwszy od ostatnich miesięcy 1946 r. na Wyspy Brytyjskie zaczęli napływać Polacy z Niemiec, Indii, Afryki Wschodniej i Libanu. Transporty z uchodźcami przybrały na sile w 1947 i 1948 r., i trwały do 1950 r. Wśród przyjeżdżających było wiele dzieci i młodzieży w wieku szkolnym. Niejednokrotnie szkoły przyjeżdżały w nienaruszonym

${ }^{88}$ W. Leitgeber, 1946 - rok decyzji $w$ sprawie rozwiazania polskich sił zbrojnych na zachodzi $w$ świetle dokumentów brytyjskich, „Zeszyty Historyczne” (Paryż) 1977, z. 42, s. 72, 79.

${ }^{89}$ IPMS, MWRiOP, sygn. A.19.III/28, Sprawa przybycia do W [ielkiej] Brytanii szkót polskich, zorganizowanych i nadzorowanych przez wojsko we Włoszech i na Bl [iskim] Wschodzie.

${ }_{90}$ W. Leitgeber, op. cit., s. 92. Według źródeł brytyjskich w kwietniu 1946 r. czekało na demobilizację 228 tys. obywateli polskich

91 IPMS. MWRiOP, sygn. A. 19. III/ 116 ( cz. 1), Projekt organizacji powszechnej akcji kulturalno-oświatowej dla żotnierzy II Korpusu w Wielkiej Brytanii, Londyn, 15 lipca 1945 rok.

92 Ibidem, MWRiOP, sygn. A. 19. III/116 (cz.1), Pismo T. Sulimirskiego z 23 lipca 1946 roku do J. Aleksandrowicza w sprawie nadesłania informacji o szkołach II Korpusu Polskiego.

93 Polscy studenci - zotnierze we Włoszech 1945-1947, oprac. R. Lewicki, Caldra House, 1996, s. 168, 171; A. Sudoł, Edward Franciszek Szczepanik. Ostatni premier rząu RP na uchodźstwie, Wydawnictwo Uniwersytetu Kazimierza Wielkiego, Bydgoszcz 2009, s. 47.

94 IPMS, MWRiOP, sygn. A.19.III/68, Pismo H.H. Eggersa z 23 sierpnia 1946 roku do T. Sulimirskiego, zawierające wytyczne w sprawie polityki oświatowej rządu brytyjskiego wobec polskich uchodźców. 
stanie organizacji ${ }^{95}$. Sytuacja ta zmuszała kierowany przez Sulimirskiego Dział Oświaty do kolejnych działań o charakterze organizacyjnym.

Szybko rosnąca liczba rodzin polskich w Wielkiej Brytanii spowodowała, że parlament tego kraju zajął się kwestią edukacji młodego pokolenia uchodźców polskich i uchwalił w marcu 1947 r. ustawę o osiedleniu Polaków. Na podstawie tego aktu prawnego minister edukacji i sekretarz stanu dla Szkocji utworzyli 1 kwietnia 1947 r. Komitet do Spraw Oświaty Polaków w Wielkiej Brytanii (Comittee for the of Poles in Great Britain). Istniał on do 30 września 1954 r. W jego skład wchodziło zawsze trzech Polaków. Polskim dyrektorem tej instytucji został Stanisław Szydłowski. Prof. Tadeuszowi Sulimirskiemu przypadła funkcja doradcy oświatowego. Początkowo Komitet zatrudniał 130 osób, a w 1951 r. wraz z placówkami około 750. Równocześnie zlikwidowano $\mathrm{z}$ dniem 31 marca tegoż roku ITC $^{96}$

Kończąc swoją działalność, Dział Oświaty pozostawił Komitetowi Oświaty 21 przedszkoli i szkół, do których uczęszczało 1607 dzieci i młodzieży. Istniały jeszcze, chociaż stopniowo wygaszane, polskie wydziały przy uczelniach angielskich i szkockich. Z funduszy brytyjskich wypłacano stypendium 488 osobom studiującym na uczelniach angielskich. Bardziej szczegółowe informacje na ten temat zawiera zamieszczona poniżej tabela.

Tabela. Szkoły polskie zarządzane przez Komitet dla Spraw Oświaty Polaków w Wielkiej Brytanii w dniu 1 kwietnia $1947 \mathrm{r}$.

\begin{tabular}{|l|c|c|}
\hline \multicolumn{1}{|c|}{ Rodzaj placówki } & \multicolumn{2}{c|}{ Liczba } \\
\cline { 2 - 3 } & placówek & uczniów \\
\hline Przedszkola & 6 & 146 \\
\hline Szkoły powszechne & 8 & 304 \\
\hline Szkoły średnie ogólnokształcące & 4 & 680 \\
\hline Szkoła średnia techniczna & 1 & 267 \\
\hline Szkoła rolnicza & 1 & 100 \\
\hline Szkoła Handlu Zagranicznego i Administracji Państwowej & 1 & 110 \\
\hline Razem szkół zawodowych & 3 & 477 \\
\hline Razem wszystkich szkół & 21 & 1607 \\
\hline Stypendyści Komitetu w szkołach angielskich & - & 488 \\
\hline
\end{tabular}

Źródło: Ministry of Education, Education in Exile. History of the Committee for the Education of Poles in Great Britain, Her Majestysty's Stationer Office, London 1956, s. 52; T. Radzik, Brytyjska pomoc..., op. cit., s. 360.

95 B. Czaykowski, B. Sulik, Polacy w W. Brytanii, Instytut Literacki, Paryż 1961, s. 107-109.

96 S. Szydłowski, Studia wyższe..., op. cit., s. 37-38. Opis działalności Komitetu Oświatowego znajduje się w: Ministry of Education, Education in Exile. History of the Committee for the Education of Poles in Great Britain, Her Majestysty's Stationer Office, London 1956. 
Po zarządzeniu przez władze brytyjskie zakończenia działalności Tymczasowego Komitetu Skarbu do Spraw Polskich T. Sulimirski z troską odniósł się do przyszłego zatrudnienia dotychczasowych pracowników Działu Oświaty przez nową instytucję, zajmującą się sprawami polskiego szkolnictwa. Prosił wszystkich podległych mu do tej pory kierowników wydziałów i placówek edukacyjnych, aby zadbali o podległych im nauczycieli i wszystkich bez wyjątku pracowników, aby kontynuowali swoją pracę dla dobra szkolnictwa. Treść tego apelu, wystosowana w trudnej sytuacji do Polaków w Wielkiej Brytanii, świadczy o wielkości patriotycznego ducha prof. Tadeusza Sulimirskiego ${ }^{97}$.

Kierując Działem Oświaty ITC, wykazał wiele inicjatyw na rzecz konsolidacji społeczności uchodźczej, zadbał o edukację dzieci i młodzieży oraz doprowadził nie do szybkiej likwidacji, jak to wcześniej zakładano, a do rozwoju polskiego szkolnictwa w Wielkiej Brytanii. Bardzo wiele wysiłku włożył w otoczenie opieką finansową studentów na polskich wydziałach i uczelniach brytyjskich.

Należy też zaznaczyć, że zarządzanie Działem Oświaty i podległymi mu instytucjami edukacyjnymi w latach 1944-1947 utrudniały spory i dyskusje na temat przyszłości polskiego uchodźstwa i kwestii powrotu uchodźców do kraju. Wiele znanych postaci życia emigracyjnego na polu oświaty zdecydowało się wrócić do Polski. Uczynili to m.in.: były minister, ks. Zygmunt Kaczyński, doc. Jan Hulewicz, doc. Marian Książkiewicz, dr Jan Konopnicki i kilku absolwentów studiów pedagogicznych i psychologicznych w Edynburgu, a wśród nich przyszli, znani profesorowie Aleksander Hulek i Bolesław Hornowski. Wyjazd tych i jeszcze kilkunastu innych znanych osób osłabił potencjał intelektualny szkolnictwa na uchodźstwie.

\section{Zakończenie}

Prof. Tadeusz Sulimirski postanowił zostać na emigracji. Sprowadził do Wielkiej Brytanii swoją rodzinę. Jako doradca pracował w Komitecie Oświatowym do 1950 r., nie była to już jednak funkcja decyzyjna. W latach 1950-1953 zarabiał na życie przekładami na język angielski. Był m.in. w latach 1953-1955 wykładowcą archeologii Europy Wschodniej na Uniwersytecie w Cambridge, a od 1957 do 1969 r. pracował na Uniwersytecie w Londynie, skąd przeszedł na emeryturę. W tym czasie prowadził także odczyty i wykłady o tematyce archeologicznej w USA i wielu krajach Europy. Organizował wycieczki studentów Uniwersytetu w Londynie i prowadził badania archeologiczne na terenie Związku Radzieckiego. Utrzymywał kontakt z polskimi ośrodkami archeologicznymi. Swoimi osiągnięciami naukowymi zdobył uznanie w Europie. Opublikował ponad 200 prac naukowych, w tym kilka pozycji książkowych.

${ }^{97}$ IPMS, MWRiOP, sygn. A. 19.III/44, Pismo T. Sulimirskiego z 11 marca 1947 roku do podległych kierowników w sprawie kontynuowania pracy po 31 marca 1947 roku i zadbania w tej sprawie o wszystkich pracowników. 
Był jednym z założycieli Polskiego Uniwersytetu na Obczyźnie i jego rektorem w latach 1967-1978. Współtworzył Polską Radę Naukową na Obczyźnie, a następnie Polskie Towarzystwo Naukowe na Obczyźnie. Należał do wielu innych organizacji naukowych i społecznych. Przez kilka lat był jej prezesem. Jako redaktor wydawał w latach 19511964 „Rocznik Polskiego Towarzystwa Naukowego na Obczyźnie” i opublikował trzy zeszyty wydawnictwa ciągłego „Nauka Polska na Obczyźnie”98.

Prof. Tadeusz Sulimirski poniósł wielkie zasługi w zakresie organizowania i zarządzania polskim szkolnictwem na uchodźstwie w latach 1941-1947. Był jedną z czołowych postaci Urzędu Oświaty i Spraw Szkolnych oraz Ministerstwa Wyznań Religijnych i Oświecenia Publicznego. Wykazał się wieloma inicjatywami, zmierzającymi do rozwinięcia i usprawnienia działalności wszelkich form polskiego szkolnictwa na obczyźnie. Szczególnie blisko współpracował z gen. Józefem Hallerem. Wiele uwagi poświęcał działalności polskiego szkolnictwa wyższego na obczyźnie. Po cofnięciu uznania rządowi polskiemu w Londynie przez rząd Wielkiej Brytanii został kierownikiem Działu Oświaty The Interim Treasury Committee for Polish Questions. Na stanowisku tym wykazał się wielką kreatywnością i zdolnościami organizacyjnymi. Umiejętnie koordynował stopniową likwidacją szkolnictwa polskiego w Wielkiej Brytanii, a także w pewnym stopniu w jej dominiach. Przejawiał wielką troskę o warunki materialne polskich studentów w Wielkiej Brytanii i na Bliskim Wschodzie. Uczestniczył w akcji przyjmowania na ziemi brytyjskiej ewakuowanych z Włoch szkół i uczniów 2 Korpusu gen. Władysława Andersa. W latach powojennych był aktywnym uczestnikiem życia polskiego środowiska naukowego w Wielkiej Brytanii.

Zmarł nagle 20 czerwca 1983 r. w Londynie. Pochowany został w rodzinnych Kobylanach na Rzeszowszczyźnie, w ukochanej Ojczyźnie, której wiernie służył przez całe swoje długie, niezwykle pracowite i owocne życie.

\section{Bibliografia}

Źródła archiwalne

Archiwum Nauki Polskiej Akademii Nauk i Polskiej Akademii Umiejętności w Krakowie sygn. PAU I-39

Instytut Polski i Muzeum im. Władysława Sikorskiego w Londynie Kol. 548/8, Kol. 548/11, Kol. 548/13,.

Zespół: Ministerstwo Wyznań Religijnych i Oświecenia Publicznego: sygn. A.19. I/7, A.19. I/9. A.19. I/10/ a-d, A.19. I/ 11, A.19. I/13 c, A.19. I/17, A.19.I/18, A.19.II/3, A.19.III/28, A.19. II/29, A. 19 III/44, A.19. II/47, A.19. II/52 A.19. III/58, A.19.III/68, A.19. III/116 (cz. 1), A.19. $\mathrm{VI} / 20$.

Muzeum Wojska Polskiego w Warszawie sygn. mwp12467c, mwp13258c.

98 W. Rojek, op. cit., s. 33-41. 


\section{Źródła drukowane i opracowania}

Atlas grodzisk i zamczysk śląskich z. 1, (oprac.) J. Żurowski, R. Jakimowicz, Kraków 1939.

Chmielewski W., Działalność oświatowa Urzędu Ministra Gen. Broni Józefa Hallera, „Przegląd Historyczno-Oświatowy" 2013, nr 3-4.

Chmielewski W., Działalność wydawnicza polskich władz oświatowych na uchodźstwie w latach 1940-1945, „Przegląd Historyczno-Oświatowy” 2013, nr 1-2.

Chmielewski W., Pogląy gen. Józefa Hallera na wychowanie w latach 1940-1943, „Przegląd Historyczno-Wojskowy" 2009, nr 4.

Chmielewski W.J., Polska administracja szkolna w latach 1944-1950, wyd. 2, Piotrków Trybunalski 2010.

Chmielewski W., Przygotowanie kadr oświatowych na uchodźstwie, Seria: Monografie z Dziejów Oświaty, t. XVIII, Instytut Historii Nauki im. Ludwika i Aleksandra Birkenmajerów Polskiej Akademii Nauk, Warszawa 2013.

Chmielewski W., Z działalności Komitetu Wydawnictw Ślaskich Polskiej Akademii Umiejętności w latach 1933-1939, „Studia Śląskie”, Seria nowa, 1976, t. XXIX.

Chyrowiacy. Stownik biograficzny wychowanków Zakładu Naukowo-Wychowawczego OO. Jezuitów w Chyrowie 1886-1939, (oprac.) L. Grzebień, J. Kochanowicz, J. Niemiec, Kraków 2000.

Czaykowski B., Sulik B., Polacy w W. Brytanii, Paryż 1961.

Danilewicz M., Biblioteka Polska w Londynie, „Nauka Polska na Obczyźnie” 1958, z. 2.

Dekret Prezydenta Rzeczypospolitej z dnia 1 maja 1941r. o utworzeniu Urzędu Oświaty i Spraw Szkolnych, Dziennik Ustaw Rzeczypospolitej Polskiej 1941, nr 3, poz. 5.

Draus J., Działalność oświatowa Łukasza Kurdybachy w latach 1940-1946, „Rozprawy z Dziejów Oświaty" 1984, t. XXVI.

Dziat urzędowy. Zwolnienia i mianowania ministrów, Dziennik Ustaw Rzeczypospolitej Polskiej 30 listopada 1944, nr 14, część II.

Gajewski R., Ks. Zygmunt Kaczyński Kapłan i polityk, Lublin 2013.

Grabski S., Pamiętniki, t. 2, do druku przygotował i wstępem opatrzył W. Stankiewicz, Warszawa 1989.

Gurba J., Profesor Tadeusz Sulimirski (IIV 1898 - 21VI 1983), „Rocznik Polonijny” 1984-1985, nr 5-6.

Haller J., Pamiętniki z wyborem dokumentów i zdjęć, Łomianki 2015.

Hulewicz J., Wydawnictwa ślaskie Polskiej Akademii Umiejętności, w: Polska Akademia Umiejętności 1872-1952. Nauki humanistyczne i społeczne. Materialy z sesji jubileuszowej, Kraków, 3-4 V1973, Zakład Narodowy im. Ossolińskich Wydawnictwo Polskiej, Wrocław 1974.

Jasnowski J., Prof. Tadeusz Sulimirski jako organizator szkolnictwa polskiego na emigracji, „XXVII Rocznik Polskiego Towarzystwa Naukowego na Obczyźnie 1984/84” (Londyn) 1984.

Jażdżewski K., Z okazji 70-lecia urodzin profesora Tadeusza Sulimirskiego, „Prace i Materiały Muzeum Archeologicznego i Etnograficznego w Łodzi”, Seria Archeologiczna 1968, nr 15.

Leitgeber W., 1946 - rok decyzji w sprawie rozwiazania polskich sit zbrojnych na zachodzie w świetle dokumentów brytyjskich, „Zeszyty Historyczne” (Paryż) 1977.

Ministry of Education, Education in Exile. History of the Committee for the Education of Poles in Great Britain, London 1956.

Polscy studenci - żotnierze we Włoszech 1945-1947, R. Lewicki (oprac.), Caldra House, 1996.

Radzik T., Brytyjska pomoc edukacyjna, w: Mobilizacja uchodźstwa do walki politycznej 19451990, Londyn 1995. 
Radzik T., Profesor Tadeusz Sulimirski - archeolog (1898-1983), w: Kimmerowie, Scytowie i Sarmaci. Księga poświęcona pamięci profesora Tadeusza Sulimirskiego, J. Ciborowski (red.), Kraków 2004.

Rocznik Polskiej Akademii Umiejętności Rok 1937/1938, Kraków 1939.

Rojek W., W stużbie Polski i nauki Tadeusz Sulimirski (1898-1983), w: Kimmerowie, Scytowie i Sarmaci. Księga poświęcona pamięci profesora Tadeusza Sulimirskiego, J. Chochorowski (red.), Kraków 2004.

Sprawozdanie z działalności Komitetu Wydawnictw Śląskich Polskiej Akademii Umiejętności za czas od 28 listopada 1935 do 21 listopada 1936 oraz program prac na rok budżetowy 1937/38. Drukowane jako rękopis, Polska Akademia Umiejętności, Kraków 1937.

Sudoł A., Edward Franciszek Szczepanik. Ostatni premier rząu RP na uchodźstwie, Bydgoszcz, 2009.

Sulimirski T., Fundusz Kultury Narodowej, „Nauka Polska na Obczyźnie 1939-1960” 1961, z. 3.

Sulimirski T., Nauka polska na obczyźnie 1939-1954, „Nauka Polska na Obczyźnie” 1955, z. 1.

Sulimirski T., Studium Pedagogiczne w Edynburgu (1943-1946), „Nauka Polska na Obczyźnie” 1955, z. 1.

Szydłowski S., Studia wyższe Polaków w Wielkiej Brytanii, „Nauka Polska na Obczyźnie 19391960" 1961, z. 3. 